\title{
UURNAL KEUANGANDANBISNIS
}

\section{Vol. 16, No. 1, Maret 2018}

Analisis Dengaruh Kecerdasan Intelehtual Terhadap Kemampuan Akuntansi Dengan Kecerdasan Emosional Dan spiritual sebagai Pemoderasi Ria Manurung

Perbedaan Persepsi Mahasiswa Program studi Akuntansi dan Manajemen Terhadap Kualitas Layanan Jasa Pendidikan di Universitas Katolik Musi Charitas Dalembang Maria Josephine Tyra dan Andreas Sarjone

Pengaruh Kualitas Produk dan Kualitas Pelayanan Terhadap Kepuasan Pelanggan Mobile Broadband di Kota Palembang Hendrianto, Diah Natalisa, dan Dian Eka

Analisis Pengaruh Diversitas Gender, Kepemilikan Institusional, dan Ukuran Perusahaan Terhadap Kinerja Keuangan Lisaime dan Dewi sri

Demografi Terhadap Pengambilan Keputusan Investasi

(Studi Kasus Degawai Kantor Badan Kepegawaian Daerah sumatera Selatan) Nyimas Artina dan Idham Cholid

Dengaruh Drofitabilitas, Opini Auditor, dan Ukuran Perusahaan Terhadap Ketepatan Waktu Penyampaian Laporan Keuangan di Bursa Efek Indonesia Periode Tahun 2012-2014

Hefi Dwi Ohtavia dan Diah Hari Saryaningrum

Pengaruh strategi Prospector dan Defender, Kompensasi Eksekutif dan Ukuran Perusahaan Terhadap Nillai Derusahaan

Ratih Yani Lestari, Brigita Dilla Savirach, Oktavia, dan Novita Febriany

Universitos Kotolik Musi Chailitos

$$
\text { Palembong }
$$




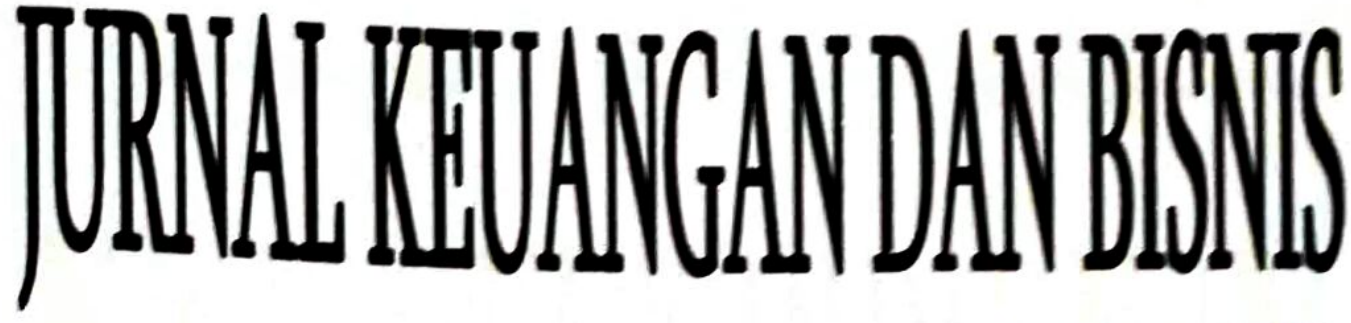

Vol. 16, No.1, Maret 2018

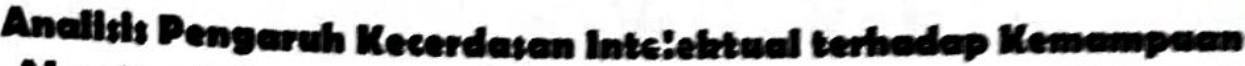

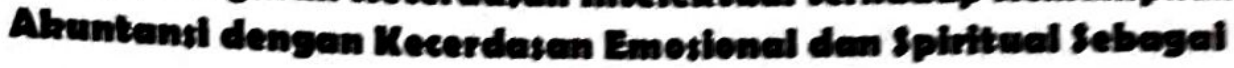
Demoderest Die Mamenrung

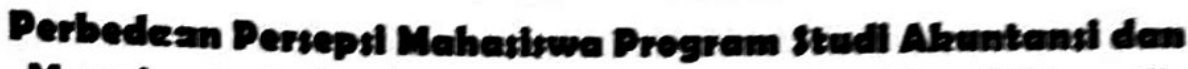

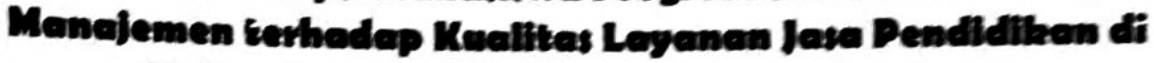
Unherstles Ketolit Mas Cheritias Dalembeng Marla Jesephlne Tyre den Andrees Serjono

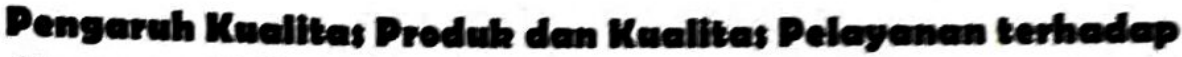

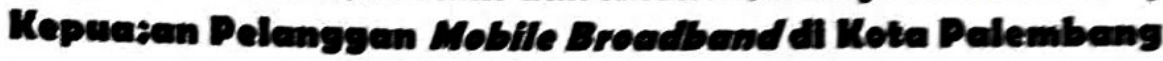
Hendrianto, Dich Netallise, den Dieh Eha

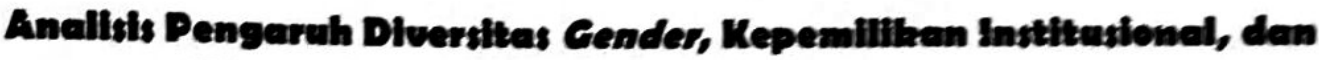
Ukuren Perasahean terhadep Kinerja Kewangan Lisedme dan Dewi st

Demogrefi terhadep Pengambilan Keputusen Investaxi (Studil Kasus Pegewal Kantor Badan Kepegowalen Daerah Sumatere Seleten)

Nyimes Artine den Ldham Cholid

Pengaruh Profitabliftas, Opini Auditior, den Uburan Permsehean terhadap Ketepaten Wehtu Denyampaien Laporan Kewangen if Bursa Efeb Indonesia Periode Tahum 2012-2014 Hefi Dui Ohtevia den Dieh Heri Suryaningrum

Pengaruh Stretegl Prospector dan Defender, Kompensasi Ebsehutif dan Uturan Perusehaan terhadap Nillai Perusahean Rotilh Yuni Lesteri, Brigita Dilla Savirech, Ottevia, dan Novita Febriany

\section{Universitas Katolik Musi Charitas Palembang}




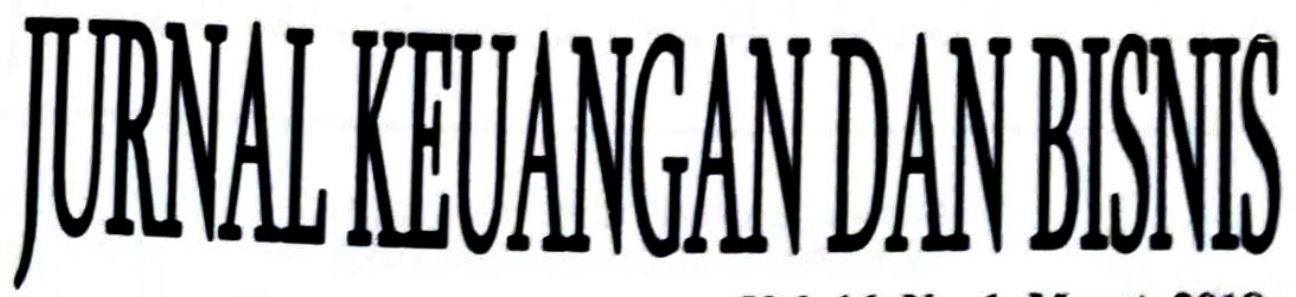

Vol. 16, No. 1, Maret 2018

PENANGGUNG JAWAB:

Rektor Universitas Katolik Musi Charitas

KETUA PENYUNTING:

Weny Putri, S.E., M.Si.

PENYUNTING PELAKSANA:

Dr. Candra Astra Terenggana, S.E., M.M.

Agatha Septiana S.R., S.E., M.Si.

Fadilla, S.E.I.,M.Si

Dr. Hj. Sa'adah Sidiq, S.E., Ak.,M.Si.

Catharina Clara, S.E., M.Si.

Yohanes Andry Putranto, S.E., M.Sc., Ak.

Dewi Sri., S.E.,M.Si.,Ak.,CA

Feby Astrid Kesaulya, S.E., M.Sc.

TATA USAHA:

Dra. Natalia Maria Sri Kusniwati, S.S.

DISTRIBUSI \& SIRKULASI:

Paulina

ALAMAT REDAKSI:

Lembaga Penelitian dan Pengabdian kepada Masyarakat Universitas Katolik Musi Charitas Palembang

Jl. Bangau No. 60 Palembang 30113

Telp/Fax (0711) 369728 / 321801

www.ukmc.ac.id

e-mail:

ikb@ukmc.ac.id 


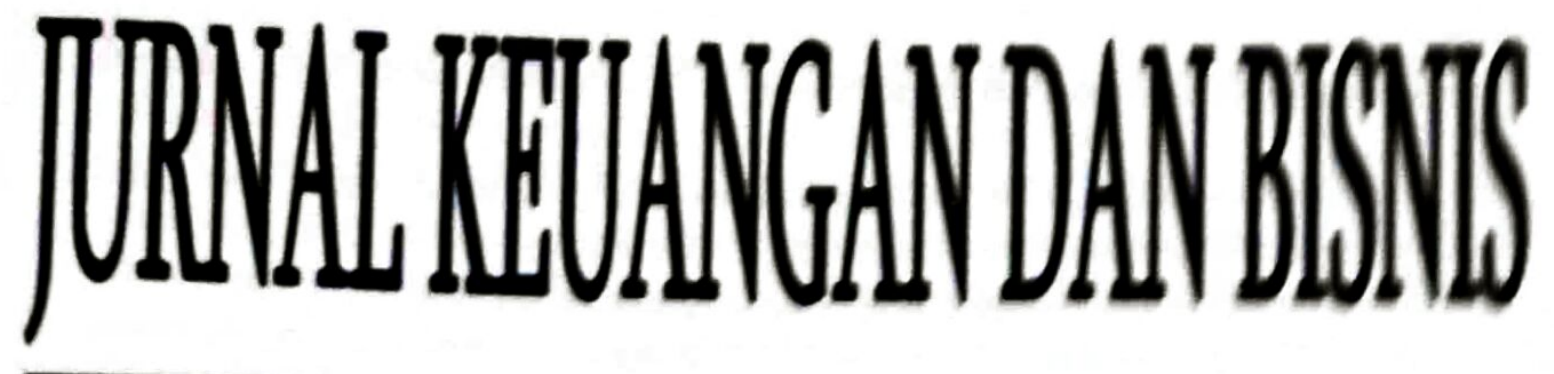

\section{KEBLSAKAN PENYUNTINGAN DAN \\ PEDOMAN PENULISAN ARTIKEI.}

\section{KebIJAKAN EdTrorIaL}

JURNAL KEUANGAN DAN BISNIS (JKB) ditenbitkan glei Niniversites Katolik Musi Charitas secara berkala dua kali setahun yaity bulan Merat den Oktober. Tujuan penerbitan JKB adalah untuk menyebarluasken hasilf hesil penelitian kepada para akademisi dan praktisi yang tertarik pada bidang kewangen dan bisnis. Lingkup isi artikel yang dimuat dalam JKB ini adalah bidang exomanni, manajemen dan akuntansi.

JKB menerima kiriman artikel yang ditulis dalam Bahase lindonesie dew Bahasa Inggris. Artikel yang dikirimkan hendaknya mengikuti pedoman penulisan artikel yang telah ditentukan oleh editor pelaksana Jurnal Keuangan dan Bisnis.

Penentuan artikel yang akan dimuat dalam jumal ini dilakukan olch editor pelaksana dan mitra bestari dengan proses blind review dengan pertiminamgan terpenuhinya syarat baku publikasi jurnal, mempunyai metodologi yang jelas dan mempunyai kontribusi bagi pengembangan ilmu dan praktik. Ediuon peluk sana dan mitra bestari bertanggung jawab untuk memberikan telaah knosiruknif umadep artikel yang akan dimuat dan jika memang perlu akan memberikan basil cvaluari artikel kepada penulis.

Artıkel dapat dikirimkan dalam bentuk soft file melalui amail alew CDR dilengkapi dengan hardfile (tercetak) I eksemplar ke alamal:

Lembaga Penelitian dan Pengabdian kepada Masyarakat (1.PPM)

Universitas Katolik Musi Charitas

Jl. Bangau No. 60 Palembang 30113

Telp./Fax. (0711) $369728 / 378170$

www.ukmc.ac,id

e-mail:

jkb@ukme.ac.id 


\section{Pedoman Penulisan Artikel}

Berikut ini adalah ketentuan-ketentuan yang harus diperhatikan penulis dalara menulis artikel untuk Jumal Keuangan dan Bisnis:

1. Artikel diketik dengan jarak 1 spasi pada kertas $A 4$.

2. Panjang artikel sebanyak $20-25$ halaman.

3. Margin kiri, kanan, atas dan bawah 1 inci.

4. Halaman muka (cover) berisi judul artikel dan identitas penulis (pekerjaan dan asal institusi. alamat email, dan nomor telepon)

5. Setiap tabel dan gambar diberi nomor urut. No tabel ditempatkan diatas judul tabel, dan dituliskan ditengah (centered).

6. Tampilan tabel adalah berbentuk classic (tanpa garis vertikal)

7. Kutipan dalam teks sebaiknya ditulis diantara kurung buka dan kurung tutup yang menyebutkan nama akhir penulis, tahun, dan no hal jika dipandang perlu. Contoh:

a. Satu sumber kutipan dengan satu penulis (Foster, 1986), jika disertai nomor halaman (Foster, 1986:98)

b. Satu sumber kutipan dengan lebih dari dua penulis (Terenggana dkk.,2013) atau (Beaver et al., 1970)

c. Dua sumber kutipan dengan penulis yang berbeda (Fisher, 1959, Altman, 1987)

d. Dua sumber kutipan dengan penulis yang sama maka dicantumkan nama pertama (Merchant, 1981; 1984), jika tahun publikasi sama (Merchant, 1988a; 1988b)

e. Sumber kutipan yang berasal dari pekerjaan suatu institusi sebaiknya menyebutkan akronim institusi yang bersangkutan (IAI, 2000)

8. Setiap artikel harus memuat daftar pustaka (hanya yang menjadi sumber kutipan).

9. Sistematika penulisan artikel adaiah:

Judul: jumlah kata tidak boleh lebih dari 12 kata dalam tulisan bahasa Indonesia atau 10 kata dalam bahasa Inggris. Font judul 12 menggunakan huruf kapital.

Nama penulis: nama lengkap dituliskan tanpa gelar, dituliskan setelah judul. Font 12, huruf kapital.

Abstract dan Abstraksi: memuat latar belakang masalah, pendekatan pemecahan masalah, dan hasil yang dicapai. Abstract dituliskan setelah nama penulis dan masing-masing terdiri dari 100-300 kata dalam Bahasa Inggris dan Bahasa Indonesia.

Keywords dan Kata Kunci: terdiri dari 3-6 kata yang ditulis secara urut dari khusus keumum dalam satu baris

PENDAHULUAN: menguraikan latar belakang, masalah dan tujuan penelitian.

TELAAH TEORETIS DAN PENGEMBANGAN HIPOTESIS (jikaada): mengungkapkan kerangka berpikir logis untuk mengembangkan hipotesis dan model penelitian (jika ada) berdasarkan literatur-literatur yang dipakai sebagai landasan teori.

METODE PENELITIAN: diuraikan secara terperinci mengenai populasi, sampel, data, pengukuran variabel, dan alat analisis yang digunakan. 
HASIL DAN PEMBAHASAN: menguraikan hasil dari analisis data sesuai tujuan penelitian dan dilengkapi dengan penjelasan hasil.

KESIMPULAN DAN IMPLIKASI: memuat jawaban atas masalah penelitian berdasarkan hasil analisisnya. Kemudian juga bisa diungkapkan keterbatasan yang ada dalam penelitian tersebut dan memberikan masukan untuk penelitian selanjutnya.

DAFTAR PUSTAKA

a. Daftar pustaka disusun alfabetis

b. Susunan setiap pustaka adalah nama penulis, tahun publikasi, judul jurnal artikel atau buku teks, nama jurnal atau penerbit, no hal.

c. Contoh penulisan daftar pustaka:

1) Artikei yang berasal dari jurnal

Mooij, Marieke de dan Geert Hofstede. 2010. The Hofstede Model Application to Global Branding and Advertising Strategy and Research. International Journal of Advertising 29(1), 85-110

Triyonodan Yogiyanto Hartono. 2000. Hubungan Kandungan Informasi Arus Kas, Komponen Arus Kas, dan Laba Akuntansi dengan Harga dan Return Saham. Jurnal Riset Akuntansi Indonesia, Vol 3 No 1. Hal 24-38

2) Sumber dari artikel dari kumpulan artikel (seperti proceding, dll)

Ninna Daniatidan Suhairi. 2006. Pengaruh Kandungan Informasi Komponen Laporan Arus Kas, Laba Kotor, dan Size Perusahaan terhadap Expected Return Saham, Proceeding Simposium Nasional Akuntansi IX., Padang

3) Sumber dari buku

Suwarjono. 2006. Teori Akuntansi Perekayasaan dan Pelaporan Keuangan. Edisi 5 .BPFE-Yogyakarta.Yogyakarta.

Abdul HalimdanMamduh M. Hanafi. 2003. Analisis Laporan Keuangan. Edisi 2.UPP AMP-YKPN.Yogyakarta.

4) Artikel dalam Koran

Mas Achmad Daniri dan Maria Dian Nurani. 2007. Menuju Standarisasi CSR. Harian Bisnis Indonesia. Terbitan 19 Juli 2007. Hal 3.

Yuliana, 2001, Hambatan Internal dan Eksternal Pembangunan Usaha Kecil, Sumatera Post. Terbitan 27 Juli 2001. Hal 2.

5) Sumber informasi dari pengarang tidak dikenal

Ikatan Akuntan Indonesia. 2009. Standar Akuntansi Keuangan. Salemba Empat. Jakarta.

6) Sumber berupa karya terjemahan

Ahmed Riahi, Belakoui. 2007. Teori Akuntansi.Terjemahan: Ali Akbar Yulianto dan Krista. 2011. Salemba Empat. Jakarta

7) Makalah yang disajikan dalam seminar, penataran atau lokakarya 
Takwim. 2005. Habifus: Perlengkapan dan Kerangke Panduan Goyo
Hidup. Makalah pada acara Extension Course 'Resistensi Cous

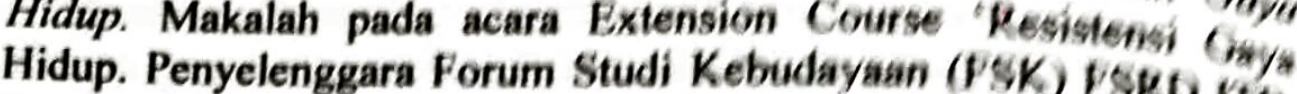

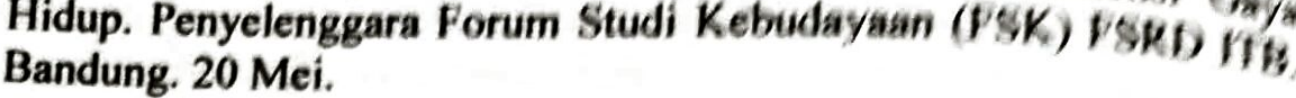

8) Artikel dari koran atau majalah tanpa nama penulis

Majalah Marketing. 2007. CSR Bukan Uniuk Laba-Kugi Semata, Voing 11/2007. Hal 36.

Kompas. 1996. Kekerasan Struktural. Terbitan 28 Agustus 1996. Hal 45.

9) Artikel dari internet

Manurung, Adler.2007, Issue Wanita: Berani main saham, femina online, (http://www.femina.co id),diakses 2 September 2009.

Jalal. 2006. Tanggung Jawab Sosial Perusahaan di Indonesia, Koran Tempo (online). Terbit 26 September 2006 (Http://www.tempo.com).Diakses tanggal 24 september 2010.

Roy. 2005. Pengukuran Variabel dalam Penelitian. Jurnal IImu $\begin{array}{lll}\text { Pendidikan (online).Jilid } 5, & \text { No. } \\ \text { (http://www.malang.ac.Id).Diakses tanggal } 12 \text { Oktober } 2006\end{array}$

\section{LAMPIRAN (Jika ada)}




\title{
PERBEDAAN PERSEPSI MAHASISWA PROGRAM STUDI AKUNTANSI DAN MANAJEMEN TERHADAP KUALITAS LAYANAN JASA PENDIDIKAN DI UNIVERSITAS KATOLIK MUSI CHARITAS PALEMBANG
}

\author{
Maria Josephine Tyra ${ }^{2}$ \\ tyra@ukmc.ac.id \\ Andreas Sarjono ${ }^{3}$ \\ andreas@ukmc.ac.id
}

\begin{abstract}
The research is aim to observe consumer behavior regarding the perception of the five dimensions of education quality including reliability, responsiveness, assurance, empathy, and physical evidence from the Musi Charitas Catholic University (MCCU). The purpose of the study is to prove whether there is a difference in the perception of education qualityfrom the students in Management and Accounting Study Program. Data collection techniques used is to spread the 5-point Likert questionnaire that is from very disagree until strongly agree. Population in this research is active student, Batch 2015/2016 untilBatch 2016/2017 Management and Accounting Study Program. Based on the results of the differences test using the Mann-Whitney test proved that the perception of Accounting studentson the quality of education $(M d n=2143)$ generaly difference and significant with the students perception of Managementon the quality of education in MCCU $(M d n=2907)$ with significance $0.008<0.05$ (Ho is rejected). If it is seen from each variable, then reliability, responsiveness, and guaranteeprove the difference of perception between student of Accounting and Management Study Program. While the variable of empathy and physical evidence didn't prove the difference of perception between student of Accounting and Management Study Program.
\end{abstract}

Keywords: Perception, Quality of education service.

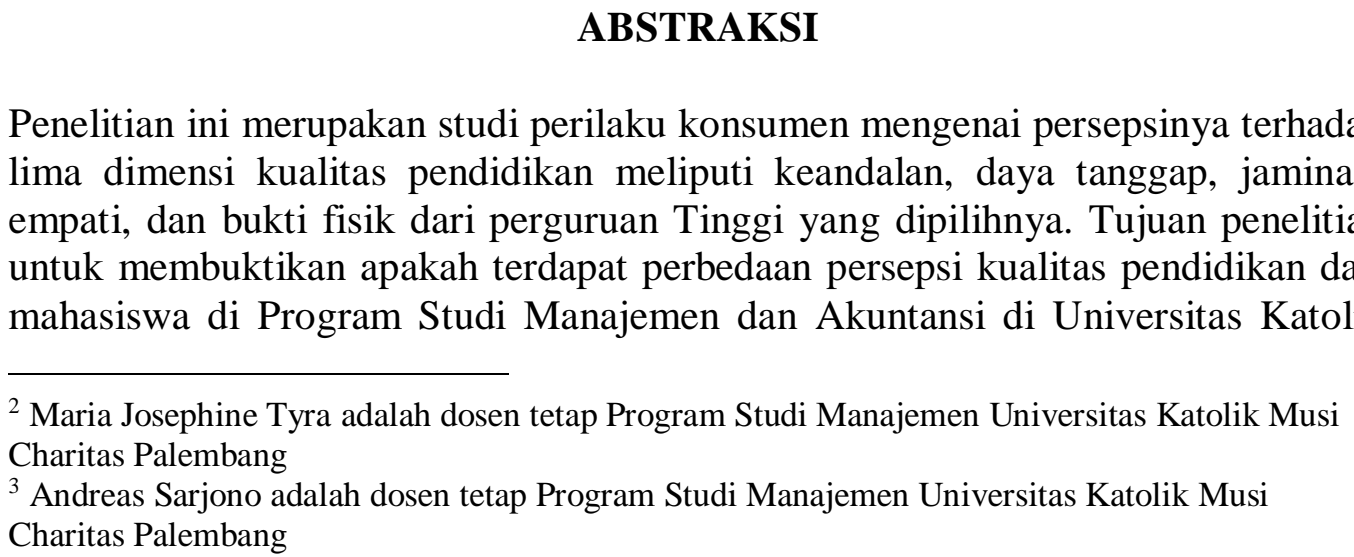


Musi Charitas.Jenis penelitian yang digunakan adalah studi kasus dengan menggunakan teknik survey. Teknik pengumpulan data yang digunakan adalah dengan menyebarkan kuesioner berskala Likert 5 poin yaitu dari Sangat tidak setuju sampai dengan Sangat setuju. Populasi dalam penelitian ini adalah mahasiswa aktif Angkatan 2015/2016 s.d. 2016/2017 Program Studi Manajemen dan Akuntansi Universitas Katolik Musi Charitas Palembang. Berdasarkan hasil uji beda dengan menggunakan uji Mann-Whitney terbukti bahwa persepsi mahasiswa Prodi Akuntansi mengenai kualitas pendidikandi Unika Musi Charitas $(\mathrm{Mdn}=2143)$ secara umum berbeda secara signifikan dengan persepsi mahasiswa Prodi Manajemen mengenai kualitas pendidikandi Unika Musi Charitas ( $\mathrm{Mdn}=$ 2907) dengan signifikansi $0.008<0,05$ (Ho ditolak). Jika dilihat dari masingmasing variabel maka untuk variabel keandalan, daya tanggap, dan jaminan membuktikan adanya perbedaan persepsi antara mahasiswa Prodi Akuntansi dengan Prodi Manajemen.Sedangkan untuk variabel empati dan bukti fisik tidak membuktikan adanya perbedaan persepsi antara mahasiswa Prodi Akuntansi dengan Prodi Manajemen.

\section{Kata kunci: Persepsi, Kualitas layanan pendidikan.}

\section{PENDAHULUAN}

Saat ini kebutuhan masyarakat terhadap pendidikan yang baik dan dapat dipercaya bukan merupakan sesuatu yang baru, tetapi dapat dikatakan sebagai suatu keharusan. Ditambah lagi dengan banyaknya pesaing yang berusaha menyediakan produk yang lebih baik dan semakin baik lagi. Menyadari kondisi yang dihadapi, maka Perguruan Tinggi sebagai penyedia jasa pendidikan sangat perlu untuk menyediakan jasa layanan pendidikan yang berkualitas meliputi keandalan (reliability), daya tanggap (responsiveness), jaminan (assurance), empati (empathy), dan bukti fisik (tangibility). Tidak mudah untuk memuaskan semua pihak baik mahasiswa sebagai pengguna jasa, maupun orangtua sebagai penyedia dana perkuliahan bagi anak pada umumnya.

Berbagai upaya telah dilakukan Perguruan Tinggi untuk menciptakan persepsi yang terbaik bagi calon mahasiswa, yang merupakan konsumennya. Misalnya membuat brosur, iklan di radio, souvenir, acara open house, talk show, presentasi, kunjungan, dan lain-lain. Semua yang dilakukan tentunya dalam rangka berupaya untuk mencerminkan keunggulan atau nilai lebih dibanding yang diberikan pesaing. Apakah semua upaya itu sungguh terbukti? Artinya siswa yang telah menjadi mahasiswa dari Perguruan Tinggi tersebut tetap memiliki persepsi yang baik setelah mereka menikmati atau memperoleh jasa yang dibelinya dari suatu Perguruan Tinggi yang dimasukinya. Persepsi konsumen menurut Robbins (1998: 90) adalah proses dimana seseorang mengorganisir dan mengartikan kesan dari panca indera dalam tujuan untuk memberi arti bagi lingkungan mereka. Artinya konsumen dengan panca indera yang dimilikinya selalu memaknai segala sesuatu yang ditemuinya atau dihadapinya sebagai sesuatu yang positif atau bahkan negatif.

Perbedaan persepsi yang terjadi setelah mengikuti perkuliahan atas kualitas layanan jasa pendidikan dapat menciptakan kepuasan atau sebaliknya yaitu menimbulkan kekecewaan. Jika kepuasan tercipta tentunya inilah yang 
diharapkan, yaitu mampu memberikan dampak positif dalam kegiatan belajar mengajar yang ditunjukkan dengan keseriusan dalam belajar dan prestasi belajar yang semakin meningkat. Akan tetapi jika kekecewaan yang muncul, maka akan berdampak pada penurunan motivasi belajar bagi mahasiswa. Kekhawatiran terbesar tentunya akan memunculkan komunikasi WOM (Words of Mouth) negatif di kalangan mahasiswa dalam menginformasikan ketidakpuasannya kepada calon konsumen dari Perguruan Tinggi yang bersangkutan. Maka dari itu, penting bagi suatu perguruan tinggi menyediakan layanan jasa pendidikan yang berkualitas, sehingga mampu menghasilkan lulusan yang dapat dihargai dalam masyarakat.Menurut Owlia dan Aspinwall (1997) dalam Haryadi, Soekarno, dan Llewelyn (2005) mengatakan bahwa kualitas pendidikan harus dilihat dari suatu sistem.Dengan pendekatan sistem, maka faktor penyebab rendahnya kualitas pendidikan tidak dilihat dari aspek guru saja, melainkan juga harus dilihat dari aspek kualitas masukan, kualitas proses, dan kualitas keluaran. Kualitas masukan mencakup kualitas peserta didik, kurikulum, pendidik, tujuan, nilai, sikap, pengetahuan, dan dana. Sedangkan kualitas proses mencakup kualitas proses belajar mengajar, penerapan teknologi, interaksi pendidik dengan peserta didik, konselor, dan administrator (Munandir:2002 dalam Haryadi, dkk.: 2005).

Sulastiyono (1999) dalam Haryadi, dkk. (2005) mendefinisikan fasilitas adalah penyediaan perlengkapan-perlengkapan fisik untuk memberikan kemudahan kepada para pemakai dalam melaksanakan aktivitas-aktivitasnya atau kegiatan-kegiatannya, sehingga segala kebutuhan-kebutuhan tersebut dapat terpenuhi dengan baik. Demikian pula dengan staf pengajar yang harus dimiliki suatu perguruan tinggi adalah staf pengajar yang efektif. Sebagai tenaga pengajar yang efektif adalah mereka yang mengetahui dengan baik subyek yang akan diajarkan, penuh perhatian terhadap para siswa, bijaksana, dan bertindak adil terhadap semua siswanya, menghargai setiap siswa, serta bertanggungjawab terhadap keberhasilan belajar siswa untuk dapat berprestasi.

Universitas Katolik Musi Charitas berdiri pada tahun 2015, merupakan konsolidasi atas tiga Sekolah Tinggi yaitu: Sekolah Tinggi Ilmu Ekonomi Musi, Sekolah Tinggi Teknik Musi, dan Sekolah Tinggi Ilmu Keperawatan. Universitas Katolik Musi Charitas merupakan Universitas Katolik pertama dan mungkin yang satu-satunya di Sumatera Bagian Selatan ini. Berbagai upaya dilakukan untuk menarik calon mahasiswa memilih Perguruan Tinggi ini sebagai wadah untuk mencapai cita-citanya. Syarat staf pengajar dipenuhi, demikian pula fasilitas penunjang pendidikan juga diupayakan walaupun masih ditemui banyak kekurangan. Tim promosi Universitas banyak menggaungkan keunggulan dari Universitas Katolik Musi Charitas baik secara lisan maupun tulisan. Semua yang dilakukan tentunya untuk dapat menciptakan persepsi yang positif dari calon mahasiswa. Program Studi Manajemen dan Akuntansi pada Fakultas Bisnis dan Akuntansi (FBA) merupakan Program Studi yang memiliki peminat lebih banyak dibandingkan Program Studi lainnya yang ada di Unika Musi Charitas.Artinya dapat dikatakan bahwa mahasiswa Prodi Manajemen dan Prodi Akuntansi memiliki persepsi yang baik terhadap kualitaslayanan jasa pendidikan yang dimiliki Universitas Katolik Musi Charitas Palembang. Akan tetapi dari data yang diperoleh melalui Kepala Kantor Administrasi Akademik diketahui bahwa jumlah 
mahasiswa Baru untuk Tahun Akademik 2014/2015 s.d. 2016/2017 mengalami penurunan terus menerus. Data dapat dilihat pada tabel 1 di bawah ini.

Tabel 1

Jumlah Mahasiswa/i. Baru, Tahun Akademik 2014/2015 s.d. 2016/2017

\begin{tabular}{ccc}
\hline Tahun Akademik & Prodi Akuntansi & Prodi Manajemen \\
\hline $2014 / 2015$ & 152 & 128 \\
\hline $2015 / 2016$ & 122 & 113 \\
\hline $2016 / 2017$ & 118 & 100 \\
\hline
\end{tabular}

Sumber: Ka.KAA

Berdasarkan Tabel 1 dapat dilihat bahwa jumlah mahasiswa baru TA 2014/2015 s.d.2016/2017 terus mengalami penurunan. Selain itu jika dilihat dari data sebelum konsolidasi (masih Sekolah Tinggi Ilmu Ekonomi Musi) untuk perbedaan Jumlah Mahasiswa Registrasi dengan Jumlah yang lulus pada tahun akademik 2010/2011 s.d. 2012/2013 adalah sebagai berikut:

Tabel 2

Perbedaan Jumlah Mahasiswa Registrasi dengan Jumlah yang Lulus Tahun Akademik 2010/2011 s.d. 2012/2013

\begin{tabular}{cccccccc}
\hline TahunAkademik & \multicolumn{2}{c}{ Prodi Akuntansi } & Selisih & \multicolumn{2}{c}{ Prodi Manajemen } & Selisih \\
\cline { 2 - 3 } & Registrasi & Lulus & (orang) & Registrasi & Lulus & (orang) \\
\hline $2010 / 2011$ & 200 & 161 & 39 & 77 & 58 & 19 \\
\hline $2011 / 2012$ & 226 & 189 & 37 & 125 & 98 & 27 \\
\hline $2012 / 2013$ & 222 & 175 & 47 & 132 & 85 & 47 \\
\hline
\end{tabular}

Sumber: Ka.KAA.

Dari Tabel 2 dapat dikatakan bahwa terdapat selisih yang cukup signifikan antara jumlah ketika mereka masuk Perguruan tinggi dengan jumlah ketika mereka lulus untuk masing-masing angkatan. Terdapat kecenderungan meningkat dari tahun ke tahun baik Prodi Akuntansi maupun Prodi Manajemen. Data tersebut memunculkan berbagai pertanyaan apakah mahasiswa yang tidak menyelesaikan studinya diakibatkan ketidakmampuan mengikuti kuliah, atau ada penyebab lainnya, seperti rasa jenuh atau ketidak puasan terhadap layanan lembaga pendidikan di Unika Musi Charitas. Oleh karena itulah, ingin diketahui apakah terdapat perbedaan persepsi mengenai kualitas layanan jasa pendidikan antara mahasiswa Program Studi Manajemen dengan mahasiswa Program Studi Akuntansi, yang berdampak pada motivasi belajar mahasiswa serta citra dari Universitas Katolik Musi Charitas.

Berdasarkan latar belakang dan hasil penelitian terdahulu dinilai penting untuk melakukan penelitian mengenai kualitas layanan jasa pendidikan dengan memfokuskan pada pembuktian apakah terdapat perbedaan persepsi mahasiswa Program Studi Manajemen dan Akuntansi terhadap kualitas layanan jasa 
pendidikan di Universitas Katolik Musi Charitas, Palembang. Penelitian ini dikaji lebih lanjut untuk membuktikan apakah terdapat perbedaan persepsi mahasiswa Program Studi Akuntansi dan Manajemen terhadap kualitas layanan jasa pendidikan di Universitas Katolik Musi Charitas Palembang.

Perumusan masalah dalam penelitian ini adalah sebagai berikut:

1. Bagaimana persepsi mahasiswa Program Studi Akuntansi dan Manajemen terhadap kualitas layanan jasa pendidikan (Keandalan, daya tanggap, jaminan, empati, dan bukti fisik) di Universitas Katolik Musi Charitas, Palembang?

2. Apakah terdapat perbedaan persepsi mahasiswa Program Studi Manajemen dan Akuntansi terhadap kualitas layanan jasa pendidikan (Keandalan, daya tanggap, jaminan, empati, dan bukti fisik) di Universitas Katolik Musi Charitas, Palembang?

\section{TELAAH TEORITIS DAN PENGEMBANGAN HIPOTESIS \\ Pengertian Jasa}

Produk terdiri dari barang dan jasa. Jasa merupakan suatu pengalaman yang tidak berwujud (intangible). Jasa merupakan tindakan atau kinerja yang menghasilkanmanfaat bagi konsumen melalui perubahan yang diinginkan. (Lovelock dan Wright: 1999) Terdapat 4 ciri dari jasa (Kotler dan Keller: 2009):

1. Tidak berwujud

Tidak seperti produk fisik, jasa tidak dapat dilihat, dirasakan, diraba, didengar, atau dibaui sebelum jasa itu dibeli.

2. Tak terpisahkan

Jasa umumnya diproduksi dan dikonsumsi sekaligus.

3. Bervariasi

Kualitas jasa tergantung pada siapa yang menyediakannya, kapan dan dimana, dan kepada siapa, jasa sangat bervariasi.

4. Dapat musnah

Jasa tidak dapat disimpan, jadi dapat musnahnya jasa bisa menjadi masalah ketika permintaan berfluktuasi.

\section{Pengertian Persepsi}

Menurut Kotler dan Armstrong (2008), Persepsi adalah proses dimana orang memilih, mengatur, dan menginterpretasikan informasi untuk membentuk gambaran dunia yang berarti. Orang dapat membentuk persepsi yang berbeda dari rangsangan yang sama dikarenakan adanya 3 proses perseptual (berhubungan dengan rangsangan sensorik): atensi selektif, distorsi selektif, dan retensi selektif. Robbins (1998) mendefinisikan persepsi konsumen sebagai proses dimana seseorang mengorganisir dan mengartikan kesan dari panca indera dalam tujuan untukk memberi arti bagi lingkungan mereka. Persepsi terhadap sesuatu berasal dari interaksi antara 2 jenis faktor (Schiffman dan Kanuk: 2000) yaitu:

\section{Stimulus Factors}

Karakteristik obyek seperti ukuran, warna, berat atau bentuk.Tampilan suatu produk atau jasa mampu menciptakan suatu persepsi mengenai produk yang dilihat atau dialaminya.

\section{Individual Factors}


Persepsi konsumen merupakan suatu proses penggunaan pengetahuan yang telah dimiliki oleh konsumen untuk mendeteksi, mengumpulkan dan menafsirkan stimulus yang diterima oleh alat indera menjadi arti tertentu yang bermakna.

Menurut Robbins (1998) terdapat faktor-faktor yang mempengaruhi persepsi yaitu:

1. The Perceiver

Karakter individu yang bersangkutan, karakter tersebut dipengaruhi oleh sikap, motivasi, minat, pengalaman, serta harapan atau ekspektasi.

2. The Target

Karakteristik dan sifat dari obyek setelah diteliti dapat mempengaruhi apa yang dirasakan.

3. The Situation

Situasi mempengaruhi persepsi manusia. Waktu dan dimana obyek atau kejadian itu terlihat akan mempengaruhi perhatian.

\section{Kualitas pendidikan}

Orang yang berkualitas merupakan output dari pendidikan yang berkualitas. Kualitas pendidikan harus dilihat dari satu sistem. Melalui pendekatan sistem, maka faktor penyebab rendahnya kualitas pendidikan tidak dilihat dari aspek guru saja, melainkan juga harus dilihat dari aspek kualitas masukan, kualitas proses, dan kualitas keluaran. Menurut Owlia dan Aspinwall (1997), kualitas masukan mencakup kualitas peserta didik, kurikulum, pendidik, tujuan, nilai, sikap, pengetahuan, dan dana. Selanjutnya menurut Munandir (2002), kualitas proses mencakup kualitas proses belajar mengajar, penerapan teknologi, interaksi pendidik dengan peserta didik, konselor, dan administrator.

\section{Fasilitas}

Fasilitas adalah segala sesuatu yang dapat digunakan untuk terlaksananya suatu kegiatan yang perlu dikerjakan untuk mencapai suatu tujuan. Demikian pula menurut Sulastiyono (1999), fasilitas adalah penyediaan perlengkapanperlengkapan fisik untuk memberikan kemudahan kepada para pemakai dalam melaksanakan aktivitas-aktivitasnya atau kegiatan-kegiatannya, sehingga segala kebutuhan-kebutuhan tersebut dapat terpenuhi dengan baik. Suatu institusi pendidikan membutuhkan fasilitas untuk menunjang kegiatan belajar mengajar, kegiatan mahasiswa, administrasi pendidikan, dan kegiatan lainnya berupa ruang kelas dan peralatannya, perpustakaan, laboratorium, komputer dan internet, kantor, dan masih banyak lagi lainnya.

\section{Staf Pengajar}

Setiap institusi pendidikan membutuhkan Staf Pengajar dengan sebutan dan kualifikasi yang berbeda. Staf Pengajar di tingkat SD, SMP, SMA dikenal dengan sebutan Guru dengan kualifikasi minimal Sarjana Pendidikan setara dengan S1. Pada Perguruan Tinggi, staf pengajar disebut Dosen dengan kualifikasi minimal S2. Menurut seorang ahli pendidikan Soekartawi (1995) dalam Haryadi, dkk. (2005), profil seorang pengajar adalah: 
1. Dalam memberikan bahan ajar, seorang pengajar harus dapat bersikap fleksibel, tidak kaku pada bahan ajar yang diberikan.

2. Dapat menerima pendapat atau usul siswa yang belajar, apakah itu pendapat yang benar atau yang salah.

3. Mampu menunjukkan kepribadian yang baik.

4. Bersedia melakukan penelitian tentang ilmu pengetahuan yang diajarkan, kemudian hasil penelitian dipakai sebagai bagian dari bahan ajar. Dengan cara seperti ini, maka isi bahan ajar selalu baru (up-to-date).

5. Mempunyai keterampilan atau cara yang spesifik dalam membuat pertanyaan-pertanyaan untuk mendorong motivasi siswa. Bila motivasi terjadi, maka penyampaian bahan ajar menjadi menarik dan siswa menjadi lebih berpartisipasi dalam mengikuti pengajaran.

6. Menguasai ilmu pengetahuan (bahan ajar) yang diberikan. Pengajar harus siap dengan bahan ajar yang diberikan, diatur secara sistematis sesuai dengan satuan acara pengajaran yang telah ditetapkan.

7. Menyiapkan bahan evaluasi (bahan ujian) secara jelas dan menerangkan kriteria yang dipakai di dalam melakukan evaluasi.

8. Meluangkan waktu untuk membanu siswa yang belajar, bila yang bersangkutan mendapatkan kesulitan di dalam memahami isi bahan ajar yang diberikan.

9. Mempunyai sikap yang menarik dan ramah, memberikan komentar yang baik, membuat gerakan-gerakan cara mengajar yang fleksibel dan sebagainya.

10. Menggunakan cara tanya jawab.

Jadi dapat diartikan Staf Pengajar yang baik adalah tenaga pengajar yang selalu memiliki kesiapan dalam berbagi ilmu kepada anak didiknya.Bersikap adil, ramah, penuh perhatian dan bertanggungjawab atas keberhasilan dari seluruh peserta didik.

\section{Dimensi Kualitas Jasa}

Terdapat 5 (lima) dimensi dalam kualitas jasa (Parasuraman, dkk.: 1985) dalam Munawaroh (2005), yaitu:

1. Reliability: kemampuan untuk memberikan jasa dengan segera dan memuaskan.

2. Responsiveness: kemampuan untuk memberikan jasa dengan tanggap.

3. Assurance: kemampuan, kesopanan, dan sifat dapat dipercaya yang dimiliki oleh para staf, bebas dari bahaya, resiko dan keragu-raguan.

4. Emphaty: kemudahan dalam melakukan hubungan komunikasi yang baik dan memahami kebutuhan pelanggan.

5. Tangibles: fasilitas fisik, perlengkapan, pegawai dan sarana komunikasi.

Ilyas (2013) dalam penelitiannya berjudul Pengaruh Persepsi Kualitas Pelayanan dan Persepsi Biaya Pendidikan Terhadap Kepuasan dan Loyalitas Mahasiswa/i. STIE Pembangunan Tanjung Pinang menggunakan indikator kualitas layanan jasa pendidikan sebagai berikut:

1. Dimensi Keandalan (Reliability) :

a. Registrasi tepat waktu dan tanpa kesalahan 

b. Kampus menyimpan data-data akademik dengan teliti
c. Keandalan dosen misalnya tepat waktu/tidak membatalkan pertemuan
d. Staf bersungguh-sungguh dan tulus dalam pelayanan mahasiswa
e. Kampus memberikan pelayanan sesuai dengan yang dijanjikan.
f. Kemampuan para dosen dalam mengajar mahasiswa sudah baik
g.Para dosen punya perhatian yang tulus dalam mencari solusi persoalan mahasiswa

2. Dimensi Daya tanggap (Responsiveness)

a. Ketersediaan karyawan untuk membantu mahasiswa sudah memadai

b. Ketersediaan dosen untuk membantu mahasiswa sudah memadai

c. Kecakapan dosen untuk menyelesaikan permasalahan yang muncul sudah baik.

d. Kecakapan staf untuk menyelesaikan permasalahan yang muncul sudah baik.

e. Saya jarang harus hilir mudik ketika mencari informasi di kampus ini.

f. Saluran untuk menyampaikan keluhan-keluhan mahasiswa tersedia dengan cepat.

3. Dimensi Jaminan (Assurance)

a. Keramah-tamahan dan sopan santun staf kampus sudah baik

b. Keramah-tamahan dan sopan santun dosen kampus sudah baik.

c. Produktifitas penelitian para dosen sudah baik.

d. Dokumen akademis dari dosen terjaga baik.

e. Dosen sebagai agen perubahan bagi mahasiswa

f. Tingkat keterlibatan kampus terhadap masyarakat sudah baik

g. Pengetahuan staf kampus pada peraturan dan prosedur akademik sudah baik

h. Jaminan keamanan kampus sudah baik.

i. Kemampuan dalam berkomunikasi: pada matakuliah diajarkan dengan baik oleh dosen di kampus.

4. Dimensi empati (Empathy)

a. Penatalaksanaan administrasi yang memiliki ketertarikan terbaik di hati mahasiswa

b. Akses ke fasilitas komputer mengakomodir kenyamanan mahasiswa sudah memadai

c. Akses menuju ruang kelas mudah

d. Staf rela memberi perhatian individu kepada mahasiswa sudah memadai

e. Dosen mensupport kebutuhan mahasiswa sudah memadai.

f. Ruang komputer yang selalu terbuka untuk mahasiswa sudah memadai

g. Kampus bertindak adil dan tidak memihak dalam memperlakukan individu mahasiswa sudah memadai

5. Dimensi bukti fisik (Tangibility)

a. Penampilan (kebersihan dan kerapian) para dosen dalam berpakaian sudah baik

b. Penataan layout kelas sudah baik

c. Pencahayaan dalam ruang kelas sudah memadai 
d. Tampilan gedung kuliah kampus sudah baik

e. Tingkat kebersihan kampus secara umum sudah baik

f. Peralatan pendukung belajar (infokus, $W i-F i$, dll) sudah baik.

g. Atmosphir udara sudah memadai

h. Penampilan (kebersihan dan kerapian) para karyawan sudah baik

i. Ketersediaan tempat parkir sudah memadai

j. Kurikulum pendidikan yang up to date sudah memadai

k. Banyaknya mata kuliah yang ditawarkan sudah memadai

1. Kecukupan penyediaan laboratorium komputer untuk mahasiswa sudah memadai

m. Keterkinian (up to date) komputer yang digunakan sudah memadai.

n. Keterkinian (up to date) software komputer yang digunakan sudah memadai.

o. Akses internet sudah memadai.

p. Budaya kampus, keyakinan dan nilai-nilai moral di kampus ini sudah baik.

q. Buku-buku perpustakaan sudah memadai.

\section{Penelitian Terdahulu}

Penelitian yang dilakukan oleh Haryadi, dkk. (2005) dengan judul Persepsi Kualitas Pendidikan, Fasilitas, dan Staf Pengajar di Fakultas Ekonomi, Universitas Kristen Petra, Surabaya. Hasil penelitian yang diperoleh dengan menggunakan Uji-t dua sample menunjukkan bahwa semua angkatan mengalami penurunan besar dalam persepsi terhadap para staf pengajar, terutama karena ketidaktepatan waktu dalam mengajar, tetapi juga karena staf pengajar kurang menghargai mahasiswa dan juga tidak mengajar dengan cara yang mudah diterima. Mahasiswa dari angkatan lama mengalami perubahan persepsi yang positif terhadap fasilitas dan tidak mengalami perubahan dalam persepsinya terhadap kualitas pendidikan sedangkan mahasiswa dari angkatan baru mengalami penurunan persepsi terhadap kualitas pendidikan dan fasilitas.

Penelitian yang dilakukan oleh Munawaroh (2005) dengan judul penelitian Analisis Pengaruh Kualitas Jasa Terhadap Kepuasan Pada Industri Pendidikan di Yogyakarta menggunakan 5 dimensi kualitas jasa dari Parasuraman, et.al (1985) yaitu Reliability, Responsiveness, Assurance, Empathy, dan Tangible.Hasil penelitian membuktikan bahwa penilaian kualitas jasa oleh mahasiswa sebagai konsumen yang menikmati kualitas jasa secara langsung ternyata berbeda dengan penilaian Badan Akreditasi Nasional (BAN). Ditunjukkan dengan tidak adanya perbedaan kualitas jasa antara program studi yang terakreditasi A dengan B, yaitu tangible, responsiveness, reliability dan emphaty, dimana keempatnya merupakan dasar penilaian BAN untuk membedakan penilaian peringkat akreditasi.

Demikian pula penelitian yang dilakukan oleh Imran Ilyas (2013) dengan judul penelitian Pengaruh Persepsi Kualitas Pelayanan dan Persepsi Biaya Pendidikan Terhadap Kepuasan dan Loyalitas Mahasiswa/i. STIE Pembangunan Tanjung Pinang. Hasil penelitian menunjukkan bahwa persepsi kualitas pelayanan dan persepsi biaya pendidikan berpengaruh positif terhadap kepuasan mahasiswa/i. Kualitas pelayanan mempunyai pengaruh yang lebih dominan terhadap kepuasan mahasiswa/i. daripada persepsi biaya pendidikan. 


\section{Pengembangan Hipotesis}

Menurut Kotler dan Armstrong (2008) Jasa (service) adalah bentuk produk yang terdiri dari aktivitas, manfaat atau kepuasan yang ditawarkan untuk dijual dan pada dasarnya tidak berwujud serta tidak menghasilkan kepemilikan akan sesuatu. Lembaga Pendidikan Tinggi merupakan salah satu contoh dari jasa.Suatu lembaga Pendidikan Tinggi yang menjadi pilihan konsumen tentunya yang dapat memuaskan konsumen untuk berbagai manfaat atau kepuasan yang ditawarkan meliputi unsur keandalan, daya tanggap, jaminan, empati dan bukti fisik.Unsur tersebut yang disebut sebagai unsur dari kualitas layanan jasa yang dikemukakan oleh Parasuraman, et.al.(1985).

Menjadikan suatu Lembaga Pendidikan Tinggi yang memiliki layanan berkualitas tentu tidak mudah. Berbagai upaya perlu dilakukan bukan hanya kelengkapan sarana dan prasarana saja, tetapi juga meliputi pembuatan rancangan prosedur dari layanan serta status yang dimiliki, yang dapat dianggap memiliki mutu yang setara dengan Perguruan Tinggi lainnya. Universitas Katolik Musi Charitas yang merupakan konsolidasi dari 3 (tiga) Sekolah Tinggi telah melakukan konsolidasi pada tahun 2015 secara spesifik pada Prodi Manajemen dan Akuntansi yang merupakan Prodi dengan jumlah mahasiswa terbanyak ingin membuktikan apakah mahasiswanya memiliki persepsi yang berbeda terhadap kualitas layanan jasa pendidikan di Universitas Katolik Musi Charitas, Palembang. Melalui data yang menunjukkan bahwa terdapat penurunan jumlah mahasiswa sejak tahun akademik 2014/2015 s.d. tahun akademik 2016/2017 serta selalu terdapat selisih jumlah mahasiswa yang registrasi dengan mereka yang lulus (Tabel 1.2.) dapat dipersepsikan adanya kesenjangan dari kualitas layanan jasa pendidikan dari Lembaga Pendidikan yang bersangkutan.

Ilyas (2013) dalam penelitiannya berjudul Pengaruh Persepsi Kualitas Pelayanan dan Persepsi Biaya Pendidikan Terhadap Kepuasan dan Loyalitas Mahasiswa/i. STIE Pembangunan Tanjung Pinang menggunakan indikator kualitas layanan jasa pendidikan. Hasil penelitiannya membuktikan bahwa persepsi kualitas pelayanan dan persepsi biaya pendidikan berpengaruh positif terhadap kepuasan mahasiswa/i. Kualitas pelayanan mempunyai pengaruh yang lebih dominan terhadap kepuasan mahasiswa/i. daripada persepsi biaya pendidikan.

Oleh karena itu, melalui uraian di atas serta hasil penelitian terdahulu, maka rumusan hipotesis dari penelitian ini adalah:Diduga adanya perbedaan persepsi mahasiswa Prodi Manajemen dan Prodi Akuntansi Tahun Akademik 2015/2016 sampai dengan Tahun Akademik 2016/2017 terhadap kualitas layanan jasa pendidikan di Universitas Katolik Musi Charitas Palembang.

\section{METODE PENELITIAN}

Jenis penelitian ini adalah penelitian studi kasus dengan menggunakan teknik survey dalam memperoleh data penelitian. Studi kasus menurut Uma Sekaran (2006) adalah tipe penelitian yang meliputi analisis mendalam dan kontekstual terhadap situasi yang mirip dalam organisasi lain, dimana sifat dan definisi masalah yang terjadi adalah serupa dengan yang dialami dalam situasi saat ini.Populasi dari penelitian ini adalah mahasiswa dan mahasiswi aktif dari 
Program Studi Manajemen dan Akuntansi Angkatan 2015/2016 s.d. 2016/2017 Universitas Katolik Musi Charitas Palembang.Roscoe (1975) dalam sekaran (2006) mengatakan bahwa ukuran sampel lebih dari 30 dan kurang dari 500 adalah tepat untuk kebanyakan penelitian.Oleh karena itu, jumlah sampel 100 yang digunakan dalam penelitian ini (50sampel dari Prodi Manajemen dan 50sampel dari Prodi Akuntansi) adalah tepat.

Teknik Pengambilan sampel termasuk non probability sampling dengan kategori pengambilan sampel yang bertujuan (purposive sampling). Kriteria yang ditetapkan adalah:

a. Mahasiswa/ mahasiswi Prodi Manajemen atau Prodi Akuntansi

b. Tahun Akademik 2015/2016 dan Tahun Akademik 2016/2017

Teknik analisis data yang digunakan dalam penelitian ini adalah teknik analisis data kuantitatif.Sebelum dilakukan analisis data untuk pengujian hipotesis, dilakukan uji validitas dan reliabilitas, analisis deskriptif untuk skor rata-rata (frekuensi).Selanjutnya dilakukan pengujian hipotesis dengan uji beda dua rata-rata atau disebut 2-sample t-test (jika asumsi terpenuhi) untuk dua kelompok sampel bebas (independen) dengan level of significant $(\alpha)$ sebesar $5 \%$.

Pengujian validitas dimaksudkan untuk mengetahui sah atau valid tidaknya suatu kuesioner. Suatu kuesioner dikatakan valid apabila pertanyaan pada kuesioner mampu untuk mengungkapkan sesuatu yang akan diukur oleh kuesioner tersebut. Salah satu cara yang dapat dilakukan untuk menguji validitas adalah dengan melakukan korelasi antara skor yang diperoleh pada masingmasing item pernyataan dengan skor total individu. Selanjutnya, pengujian reliabilitas merupakan alat yang diperlukan untuk mengukur suatu kuesioner yang merupakan indikator dari variabel atau konstruk. Suatu kuesioner dikatakan reliabel atau handal apabila jawaban seseorang (responden) terhadap pertanyaan adalah konsisten atau stabil dari waktu ke waktu (Ghozali: 2006).Analisis deskriptif digunakan untuk menganalisis data dengan mendeskripsikan atau menggambarkan data yang telah terkumpul sebagaimana adanya (Sugiyono: 2004).Untuk menguji hipotesis penelitian yang dirumuskan dalam Bab II digunakan analisis uji beda dua rata-rata (2-sample t-test) untuk dua kelompok sampel bebas (independent) dengan level of significant $(\alpha)$ sebesar 5\% jika asumsi terpenuhi.

\section{HASIL DAN PEMBAHASAN}

Hasil penelitian yang akan diuraikan merupakan jawaban dari dua permasalahan penelitian yang telah dirumuskan, yaitu bagaimana persepsi mahasiswa Program Studi Manajemen dan Akuntansi terhadap kualitas layanan jasa pendidikan (Keandalan, daya tanggap, jaminan, empati, dan bukti fisik) di Universitas Katolik Musi Charitas, Palembang, dan apakah terdapat perbedaan persepsi mahasiswa Program Studi Manajemen dan Akuntansi terhadap kualitas layanan jasa pendidikan (Keandalan, daya tanggap, jaminan, empati, dan bukti fisik) di Universitas Katolik Musi Charitas, Palembang.

Data yang diperoleh melalui penyebaran kuesioner diolah dengan menggunakan beberapa teknik analisis data meliputi: uji validitas, uji reliabilitas, analisis deskriptif, analisis uji beda. Pembahasannya adalah sebagai berikut: 
Uji kualitas instrumen dalam penelitian ini berupa Validitas dan Reabilitas.Uji signifikan dilakukan dengan membandingkan nilai $r$ hitung dengan $r$ tabel dengan menggunakan analisis df (degree of freedom) yaitu dengan rumus $\mathrm{df}=\mathrm{n}-\mathrm{k}$ dengan $\mathrm{n}$ adalah jumlah responden dan $\mathrm{k}$ adalah jumlah variabel independen yang digunakan. Maka $\mathrm{df}=\mathrm{n}-\mathrm{k}, \mathrm{df}=100-5=95$, maka $\mathrm{r}$ tabel $=0,1996$. Dari hasil pengujian diketahui bahwa seluruh indikator yang digunakan adalah valid karena nilai $r$ hitung lebih besar dari $r$ tabel. Sementara dari pengujian reliabilitas diketahui bahwa seluruh indikator yang digunakan adalah reliabel karena nilai Cronbach's Alpha yang diperoleh lebih besar dari 0,7.

\section{Analisis Deskriptif}

Persepsi Mahasiswa Prodi Manajemen mengenai kualitas pendidikan di Universitas Katolik Musi Charitas

Tabel 3

Persepsi Mahasiswa Prodi Manajemen Untuk Variabel Keandalan

\begin{tabular}{lllllllll}
\hline No. & \multicolumn{1}{c}{ Keterangan } & STS & TS & $\begin{array}{c}\text { Skor } \\
\text { CS }\end{array}$ & S & SS & $\begin{array}{c}\text { Total } \\
\text { skor }\end{array}$ & $\begin{array}{c}\text { Rata- } \\
\text { rata } \\
\text { skor }\end{array}$ \\
\hline 1 & $\begin{array}{l}\text { Registrasi tepat waktu } \\
\text { dan tanpa kesalahan }\end{array}$ & 0 & 2 & 15 & 136 & 50 & 203 & 4,06 \\
\hline 2 & $\begin{array}{l}\text { Kampus menyimpan } \\
\text { data akademik dengan } \\
\text { teliti }\end{array}$ & 0 & 0 & 12 & 124 & 75 & 211 & 4,22 \\
\hline & $\begin{array}{l}\text { Keandalan dosen secara } \\
\text { umum baik, misalnya } \\
\text { tepat waktu/tidak } \\
\text { membatalkan pertemuan }\end{array}$ & 0 & 2 & 30 & 124 & 40 & 196 & 3,92 \\
\hline 4 & $\begin{array}{l}\text { Staf bersungguh- } \\
\text { sungguh dan tulus dalam } \\
\text { menyelesaikan masalah } \\
\text { pelayanan mahasiswa }\end{array}$ & 0 & 0 & 42 & 120 & 30 & 192 & 3,84 \\
\hline 5 & $\begin{array}{l}\text { Kampus memberikan } \\
\text { pelayanan sesuai dengan } \\
\text { yang dijanjikan }\end{array}$ & 0 & 0 & 48 & 104 & 40 & 192 & 3,84 \\
\hline 6 & $\begin{array}{l}\text { Kemampuan para dosen } \\
\text { dalam mengajar } \\
\text { mahasiswa sudah baik }\end{array}$ & 0 & 0 & 0 & 128 & 90 & 218 & 4,36 \\
\hline 7 & $\begin{array}{l}\text { Para dosen punya } \\
\text { perhatian yang tulus } \\
\text { dalam mencari solusi } \\
\text { persoalan. }\end{array}$ & 0 & 0 & 21 & 104 & 85 & 210 & 4,2 \\
\hline
\end{tabular}

Rata-rata skor dari variabel Keandalan $\quad \mathbf{4 , 0 6}$

Sumber: data primer yang diolah.

Dari tabel 7 mengenai variabel keandalan dapat diketahui bahwa Skor tertinggi yaitu 4,36 untuk pernyataan nomor 6 "Kemampuan para dosen dalam 
mengajar mahasiswa sudah baik" artinya mahasiswa/i Program Studi Manajemen menyetujui mengenai kemampuan dosen dalam mentransfer ilmu pengetahuan termasuk juga rancangan aktifitas yang disampaikan dinilai mahasiswa sudah baik. Sedangkan skor terendah yaitu sebesar 3,84 untuk pernyataan nomor 4 yaitu "Staf bersungguh-sungguh dan tulus dalam menyelesaikan masalah pelayanan mahasiswa" dan nomor 5 yaitu "Kampus memberikan pelayanan sesuai dengan yang dijanjikan". Untuk kedua pernyataan ini dapat diartikan mahasiswa/i. sebenarnya belum terlalu mengalami layanan sesuai dengan harapan mereka. Dapat diartikan juga kemungkinan mahasiswa pernah merasakan adanya ketidak seriusan dan ketulusan dalam menangani keluhan atau menyampaikan informasi yang dibutuhkan.Selain itu mereka juga masih merasakan adanya kesenjangan untuk layanan yang seharusnya diberikan.

\section{Tabel 4}

Persepsi Mahasiswa Prodi Manajemen Untuk Variabel Daya Tanggap

\begin{tabular}{|c|c|c|c|c|c|c|c|c|}
\hline \multirow[t]{2}{*}{ No. } & \multirow[t]{2}{*}{ Keterangan } & \multicolumn{5}{|c|}{ Skor } & \multirow{2}{*}{$\begin{array}{l}\text { Total } \\
\text { skor }\end{array}$} & \multirow{2}{*}{$\begin{array}{l}\text { Rata } \\
\text {-rata } \\
\text { skor }\end{array}$} \\
\hline & & STS & TS & $\mathbf{C S}$ & $\mathbf{S}$ & SS & & \\
\hline 1 & $\begin{array}{l}\text { Ketersediaan karyawan untuk } \\
\text { membantu mahasiswa sudah } \\
\text { memadai }\end{array}$ & 0 & 0 & 51 & 112 & 25 & 188 & 3,76 \\
\hline 2 & $\begin{array}{l}\text { Ketersediaan dosen untuk } \\
\text { membantu mahasiswa sudah } \\
\text { memadai }\end{array}$ & 0 & 0 & 15 & 120 & 75 & 210 & 4,20 \\
\hline 3 & $\begin{array}{l}\text { Kecakapan dosen untuk } \\
\text { menyelesaikan permasalahan } \\
\text { yang muncul sudah baik. }\end{array}$ & 0 & 0 & 15 & 112 & 85 & 212 & 4,24 \\
\hline 4 & $\begin{array}{l}\text { Kecakapan staf untuk } \\
\text { menyelesaikan permasalahan } \\
\text { yang muncul sudah baik }\end{array}$ & 0 & 0 & 42 & 112 & 40 & 194 & 3,88 \\
\hline 5 & $\begin{array}{l}\text { Saya jarang harus hilir mudik } \\
\text { ketika mencari informasi di } \\
\text { kampus ini. }\end{array}$ & 0 & 0 & 63 & 92 & 30 & 185 & 3,7 \\
\hline 6 & $\begin{array}{l}\text { Saluran untuk menyampaikan } \\
\text { keluhan-keluhan mahasiswa } \\
\text { tersedia dengan cepat }\end{array}$ & 0 & 2 & 60 & 92 & 30 & 184 & 3,68 \\
\hline
\end{tabular}

Sumber: data primer yang diolah.

Dari data dalam Tabel 4 yaitu mengenai Daya Tanggap persepsi mahasiswa Prodi Manajemen memiliki skor tertinggi sebesar 4,24 untuk pernyataan nomor 3 yaitu "Kecakapan dosen untuk menyelesaikan permasalahan yang muncul sudah baik". Artinya dosen mampu memuaskan mahasiswa untuk pertanyaan yang diajukan maupun konsultasi yang diperlukan. Untuk skor terendah sebesar 3,68 (pernyataan 6) yaitu "Saluran untuk menyampaikan keluhan-keluhan mahasiswa tersedia dengan cepat". Saluran keluhan sebenarnya telah disediakan oleh lembaga, namun belum dimanfaatkan secara maksimal. 
Tabel 5

Persepsi Mahasiswa Prodi Manajemen Untuk Variabel Jaminan

\begin{tabular}{|c|c|c|c|c|c|c|c|c|}
\hline \multirow[t]{2}{*}{ No. } & \multirow[t]{2}{*}{ Keterangan } & \multicolumn{5}{|c|}{ Skor } & \multirow{2}{*}{$\begin{array}{l}\text { Total } \\
\text { skor }\end{array}$} & \multirow{2}{*}{$\begin{array}{c}\text { Rata- } \\
\text { rata } \\
\text { skor } \\
\end{array}$} \\
\hline & & STS & TS & CS & $\mathbf{S}$ & SS & & \\
\hline 1 & $\begin{array}{l}\text { Keramah-tamahan dan } \\
\text { sopan santun staf kampus } \\
\text { sudah baik }\end{array}$ & 0 & 6 & 42 & 96 & 45 & 189 & 3,78 \\
\hline 2 & $\begin{array}{l}\text { Keramah -tamahan dan } \\
\text { sopan santun dosen kampus } \\
\text { sudah baik }\end{array}$ & 0 & 0 & 0 & 128 & 90 & 218 & 4,36 \\
\hline 3 & $\begin{array}{l}\text { Produktifitas penelitian para } \\
\text { dosen baik. }\end{array}$ & 0 & 0 & 12 & 128 & 70 & 210 & 4,20 \\
\hline 4 & $\begin{array}{l}\text { Dokumen akademis dari } \\
\text { dosen terjaga baik }\end{array}$ & 0 & 0 & 9 & 120 & 85 & 214 & 4,28 \\
\hline 5 & $\begin{array}{l}\text { Dosen sebagai agen } \\
\text { perubahan bagi mahasiswa }\end{array}$ & 0 & 0 & 12 & 116 & 85 & 213 & 4,26 \\
\hline 6 & $\begin{array}{l}\text { Tingkat keterlibatan } \\
\text { kampus terhadap } \\
\text { masyarakat sudah baik }\end{array}$ & 0 & 0 & 27 & 108 & 70 & 205 & 4,10 \\
\hline 7 & $\begin{array}{l}\text { Pengetahuan staf kampus } \\
\text { pada peraturan dan prosedur } \\
\text { akademik sudah baik }\end{array}$ & 0 & 2 & 33 & 104 & 60 & 199 & 3,98 \\
\hline 8 & $\begin{array}{l}\text { Jaminan keamanan kampus } \\
\text { sudah baik }\end{array}$ & 0 & 0 & 30 & 116 & 55 & 201 & 4,02 \\
\hline 9 & $\begin{array}{l}\text { Kemampuan dalam } \\
\text { berkomunikasi:diajarkan } \\
\text { dosen di kampus }\end{array}$ & 0 & 0 & 9 & 132 & 70 & 211 & 4,22 \\
\hline
\end{tabular}

Sumber: data primer yang diolah.

Dapat dijelaskan melalui data pada Tabel 5 bahwa persepsi mahasiswa Manajemen untuk faktor jaminan memperlihatkan skor tertinggi sebesar 4,36 untuk pernyataan no.2 yaitu "Keramah-tamahan dan sopan santun dosen kampus sudah baik". Artinya mahasiswa menyetujui perilaku yang diperlihatkan dosen selama ini. Skor terendah sebesar 3,78 untuk pernyataan no.1 yaitu "Keramahtamahan dan sopan santun staf kampus sudah baik". Untuk staf kampus mengenai keramah tamahan dan sopan santun masih belum maksimal penilaiannya, dikarenakan seringkali mahasiswa yang dilayani dalam jumlah yang cukup banyak untuk suatu kebutuhan terjadwal misalnya pemeriksaan pembayaran uang kuliah, pendaftaran wisuda, dan lain-lain, yang dapat menimbulkan kejenuhan dan kesulitan dalam memberikan pelayanan terbaik. 
Tabel 6

Persepsi Mahasiswa Prodi Manajemen Untuk Variabel Empati

\begin{tabular}{|c|c|c|c|c|c|c|c|c|}
\hline \multirow[t]{2}{*}{ No. } & \multirow[t]{2}{*}{ Keterangan } & \multicolumn{5}{|c|}{ Skor } & \multirow{2}{*}{$\begin{array}{l}\text { Total } \\
\text { skor }\end{array}$} & \multirow{2}{*}{$\begin{array}{l}\text { Rata- } \\
\text { rata } \\
\text { skor }\end{array}$} \\
\hline & & STS & TS & CS & $\mathbf{S}$ & SS & & \\
\hline 1 & $\begin{array}{l}\text { Penatalaksanaan } \\
\text { administrasi yang memiliki } \\
\text { ketertarikan terbaik di hati } \\
\text { mahasiswa }\end{array}$ & 0 & 0 & 45 & 132 & 10 & 187 & 3,74 \\
\hline 2 & $\begin{array}{l}\text { Akses ke fasilitas komputer } \\
\text { mengakomodir kenyamanan } \\
\text { mahasiswa sudah memadai }\end{array}$ & 0 & 0 & 42 & 132 & 15 & 189 & 3,78 \\
\hline 3 & $\begin{array}{l}\text { Akses menuju ruang kelas } \\
\text { mudah }\end{array}$ & 0 & 0 & 15 & 124 & 70 & 209 & 4,18 \\
\hline 4 & $\begin{array}{l}\text { Staf rela memberi perhatian } \\
\text { individu kepada mahasiswa } \\
\text { sudah memadai }\end{array}$ & 0 & 2 & 57 & 76 & 55 & 190 & 3,80 \\
\hline 5 & $\begin{array}{l}\text { Dosen mensupport } \\
\text { kebutuhan mahasiswa sudah } \\
\text { memadai }\end{array}$ & 0 & 0 & 27 & 128 & 45 & 200 & 4 \\
\hline 6 & $\begin{array}{l}\text { Ruang komputer yang } \\
\text { selalu terbuka untuk } \\
\text { mahasiswa sudah memadai }\end{array}$ & 0 & 0 & 81 & 68 & 30 & 179 & 3,58 \\
\hline 7 & $\begin{array}{l}\text { Kampus bertindak adil dan } \\
\text { tidak memihak dalam } \\
\text { memperlakukan individu } \\
\text { mahasiswa sudah memadai }\end{array}$ & 0 & 0 & 27 & 128 & 45 & 200 & 4 \\
\hline
\end{tabular}

Sumber: data primer yang diolah

Pada Tabel 6 dapat diketahui bahwa skor tertinggi sebesar 4,18 untuk pernyataan no.3 yaitu "Akses menuju ruang kelas mudah". Artinya mahasiswa tidak menemui kesulitan dalam mencari lokasi ruangan kuliah sesuai dengan jadwal mereka. Sedangkan skor terendah sebesar 3,58 untuk pernyataan no.6 "Ruang komputer yang selalu terbuka untuk mahasiswa sudah memadai". Untuk layanan ini mahasiswa dapat merasakan adanya keterbatasan dalam menggunakan ruang komputer yang tersedia, dikarenakan ruang komputer dibuka hanya bagi mahasiswayang memiliki jadwal praktikum saja. 
Tabel 7

Persepsi Mahasiswa Prodi Manajemen Untuk Variabel Bukti Fisik

\begin{tabular}{|c|c|c|c|c|c|c|c|c|}
\hline \multirow[t]{2}{*}{ No. } & \multirow[t]{2}{*}{ Keterangan } & \multicolumn{5}{|c|}{ Skor } & \multirow{2}{*}{$\begin{array}{l}\text { Total } \\
\text { skor }\end{array}$} & \multirow{2}{*}{$\begin{array}{l}\text { Rata } \\
\text {-rata } \\
\text { skor }\end{array}$} \\
\hline & & STS & TS & $\mathrm{CS}$ & $\mathbf{S}$ & $\mathbf{S S}$ & & \\
\hline 1 & $\begin{array}{l}\text { Penampilan (kebersihan dan } \\
\text { kerapian) para dosen dalam } \\
\text { berpakaian sudah baik }\end{array}$ & 0 & 0 & 3 & 88 & 135 & 226 & 4,52 \\
\hline 2 & $\begin{array}{l}\text { Penataan layout kelas sudah } \\
\text { baik }\end{array}$ & 0 & 8 & 18 & 108 & 65 & 199 & 3,98 \\
\hline 3 & $\begin{array}{l}\text { Pencahayaan dalam ruang } \\
\text { kelas sudah memadai }\end{array}$ & 0 & 10 & 30 & 92 & 60 & 192 & 3,84 \\
\hline 4 & $\begin{array}{l}\text { Tampilan gedung kuliah } \\
\text { kampus sudah baik }\end{array}$ & 1 & 6 & 48 & 96 & 30 & 181 & 3,62 \\
\hline 5 & $\begin{array}{l}\text { Tingkat kebersihan kampus } \\
\text { secara umum sudah baik }\end{array}$ & 1 & 12 & 30 & 104 & 35 & 182 & 3,64 \\
\hline 6 & $\begin{array}{l}\text { Peralatan pendukung belajar } \\
\text { (infokus, WI-FI, dll.) sudah } \\
\text { baik }\end{array}$ & 6 & 24 & 60 & 36 & 15 & 141 & 2,82 \\
\hline 7 & $\begin{array}{l}\text { Atmosfir udara sudah } \\
\text { memadai }\end{array}$ & 2 & 8 & 45 & 84 & 40 & 179 & 3,58 \\
\hline 8 & $\begin{array}{l}\text { Penampilan (kebersihan dan } \\
\text { kerapian)para karyawan } \\
\text { sudah baik }\end{array}$ & 1 & 0 & 9 & 140 & 55 & 205 & 4,1 \\
\hline 9 & $\begin{array}{l}\text { Ketersediaan tempat parkir } \\
\text { sudah memadai }\end{array}$ & 0 & 4 & 27 & 104 & 65 & 200 & 4 \\
\hline 10 & $\begin{array}{l}\text { Kurikulum pendidikan yang } \\
\text { up to date sudah memadai }\end{array}$ & 0 & 0 & 9 & 132 & 70 & 211 & 4,22 \\
\hline 11 & $\begin{array}{l}\text { Banyaknya mata kuliah yang } \\
\text { ditawarkan sudah memadai }\end{array}$ & 0 & 0 & 6 & 132 & 75 & 213 & 4,26 \\
\hline 12 & $\begin{array}{l}\text { Kecukupan penyediaan } \\
\text { laboratorium komputer untuk } \\
\text { mahasiswa sudah memadai }\end{array}$ & 1 & 8 & 42 & 108 & 20 & 179 & 3,58 \\
\hline 13 & $\begin{array}{l}\text { Keterkinian (up to date) } \\
\text { komputer yang digunakan } \\
\text { sudah memadai }\end{array}$ & 1 & 4 & 42 & 116 & 20 & 183 & 3,66 \\
\hline 14 & $\begin{array}{l}\text { Keterkinian (up to date) } \\
\text { software komputer yang } \\
\text { digunakan sudah memadai }\end{array}$ & 1 & 0 & 33 & 128 & 30 & 192 & 3,84 \\
\hline 15 & $\begin{array}{l}\text { Akses internet sudah } \\
\text { memadai }\end{array}$ & 5 & 22 & 63 & 44 & 10 & 144 & 2,88 \\
\hline 16 & $\begin{array}{l}\text { Budaya kampus, keyakinan } \\
\text { dan nilai-nilai moral di } \\
\text { kampus ini sudah baik }\end{array}$ & 1 & 0 & 30 & 108 & 60 & 199 & 3,98 \\
\hline
\end{tabular}




\begin{tabular}{lllllllll}
\hline \hline 17 & $\begin{array}{l}\text { Buku-buku perpustakaan } \\
\text { sudah memadai }\end{array}$ & 0 & 4 & 27 & 112 & 55 & 198 & 3,96 \\
\hline \multicolumn{8}{c}{ Rata-rata skor dari variabel Bukti Fisik } \\
\hline
\end{tabular}

Sumber: data primer yang diolah.

Persepsi mahasiswa untuk variabel bukti fisik dapat diketahui melalui paparan data pada Tabel 7 dimana skor tertinggi sebesar 4,52 untuk pernyataan nomor 1 yaitu "Penampilan (kebersihan dan kerapian) para dosen dalam berpakaian sudah baik. Artinya mahasiswa telah memberikan penilaian yang sangat baik bagi penampilan dosen sebagai pengajar. Sedangkan skor terendah sebesar 2,82 untuk pernyataan no.6 yaitu "Peralatan pendukung belajar (infokus, WiFi, dan lain-lain) sudah baik". Untuk hal ini mahasiswa memberikan penilaian kurang mendekati cukup setuju.Artinya masih sering ditemui kesulitan/ketidaksediaan, ataupun hambatan dalam penggunaan peralatan pendukung belajar, yang mengganggu proses belajar mengajar di kelas. Selain itu termasuk skor rendah juga yaitu untuk pernyataan no. 15 "Akses internet sudah memadai" dengan skor rata-rata 2,88 diartikan mahasiswa masih mengalami kendala untuk melakukan akses internet yang merupakan salah satu sumber informasi yang diperlukan untuk menambah wawasan mahasiswa.

Secara keseluruhan dapat dikatakan bahwa persepsi mahasiswa Prodi Manajemen untuk kualitas pendidikan di Universitas Katolik Musi Charitas adalah baik untuk "variabel jaminan" dengan skor rata-rata tertinggi 4,13. Akan tetapi untuk "variabel bukti fisik" persepsinya adalah mendekati baik dengan skor rata-rata terendah 3,79 .

Persepsi Mahasiswa Prodi Akuntansi mengenai kualitas pendidikan Universitas Katolik Musi Charitas

Tabel 8

Persepsi Mahasiswa Prodi Akuntansi Untuk Variabel Keandalan

\begin{tabular}{|c|c|c|c|c|c|c|c|c|}
\hline \multirow[t]{2}{*}{ No. } & \multirow[t]{2}{*}{ Keterangan } & \multicolumn{5}{|c|}{ Skor } & \multirow{2}{*}{$\begin{array}{l}\text { Total } \\
\text { skor }\end{array}$} & \multirow{2}{*}{$\begin{array}{l}\text { Rata } \\
\text {-rata } \\
\text { skor }\end{array}$} \\
\hline & & STS & TS & $\mathrm{CS}$ & $\mathbf{S}$ & SS & & \\
\hline 1 & $\begin{array}{l}\text { Registrasi tepat waktu dan } \\
\text { tanpa kesalahan }\end{array}$ & 0 & 2 & 33 & 136 & 20 & 191 & 3,82 \\
\hline 2 & $\begin{array}{l}\text { Kampus menyimpan data } \\
\text { akademik dengan teliti }\end{array}$ & 0 & 0 & 15 & 156 & 30 & 201 & 4,02 \\
\hline 3 & $\begin{array}{l}\text { Keandalan dosen secara } \\
\text { umum baik, misalnya tepat } \\
\text { waktu/tidak membatalkan } \\
\text { pertemuan }\end{array}$ & 0 & 2 & 60 & 104 & 15 & 181 & 3,62 \\
\hline 4 & $\begin{array}{l}\text { Staf bersungguh-sungguh dan } \\
\text { tulus dalam menyelesaikan } \\
\text { masalah pelayanan } \\
\text { mahasiswa }\end{array}$ & 0 & 0 & 66 & 100 & 15 & 181 & 3,62 \\
\hline 5 & $\begin{array}{l}\text { Kampus memberikan } \\
\text { pelayanan sesuai dengan } \\
\text { yang dijanjikan }\end{array}$ & 0 & 0 & 69 & 100 & 10 & 179 & 3,58 \\
\hline 6 & Kemampuan para dosen & 0 & 0 & 6 & 168 & 30 & 204 & 4,08 \\
\hline
\end{tabular}




\begin{tabular}{lllllllll}
\hline & $\begin{array}{l}\text { dalam mengajar mahasiswa } \\
\text { sudah baik }\end{array}$ \\
\hline 7 & $\begin{array}{l}\text { Para dosen punya perhatian } \\
\text { yang tulus dalam mencari } \\
\text { solusi persoalan. }\end{array}$ & 0 & 0 & 9 & 152 & 45 & 206 & 4,12 \\
\hline \multicolumn{1}{c}{ Rata-rata skor dari variabel Keandalan } \\
\hline
\end{tabular}

Sumber: data primer yang diolah

Pada Tabel 8 diketahui bahwa skor tertinggi yaitu 4,12 untuk pernyataan nomor 7 yaitu "Para dosen punya perhatian yang tulus dalam mencari solusi persoalan. Artinya mahasiswa mampu menilai dengan baik setiap perhatian ataupun masukan yang diberikan dosen dalam membantu memecahkan persoalan mahasiswa. Sedangkan skor terendah yaitu sebesar 3,62 untuk pernyataan nomor 3 yaitu "Keandalan dosen secara umum baik, misalnya tepat waktu/tidak membatalkan pertemuan" dan nomor 4, "Staf bersungguh-sungguh dan tulus dalam menyelesaikan masalah pelayanan mahasiswa". Artinya mahasiswa masih menemukan adanya dosen yang tidak tepat waktu dan sesekali membatalkan perkuliahan.Demikian pula penilaian yang diberikan terhadap staf belum maksimal, karena mahasiswa masih menemukan adanya kesulitan untuk mendapatkan layanan yang diharapkan.

Tabel 9

Persepsi Mahasiswa Prodi Akuntansi Untuk Variabel Daya Tanggap

\begin{tabular}{|c|c|c|c|c|c|c|c|c|}
\hline \multirow[t]{2}{*}{ No. } & \multirow[t]{2}{*}{ Keterangan } & \multicolumn{5}{|c|}{ Skor } & \multirow{2}{*}{$\begin{array}{l}\text { Total } \\
\text { skor }\end{array}$} & \multirow{2}{*}{$\begin{array}{l}\text { Rata } \\
\text {-rata } \\
\text { skor }\end{array}$} \\
\hline & & STS & TS & CS & $\mathbf{S}$ & SS & & \\
\hline 1 & $\begin{array}{l}\text { Ketersediaan karyawan untuk } \\
\text { membantu mahasiswa sudah } \\
\text { memadai }\end{array}$ & 0 & 2 & 63 & 104 & 10 & 179 & 3,58 \\
\hline 2 & $\begin{array}{l}\text { Ketersediaan dosen untuk } \\
\text { membantu mahasiswa sudah } \\
\text { memadai }\end{array}$ & 0 & 0 & 15 & 164 & 20 & 199 & 3,98 \\
\hline 3 & $\begin{array}{l}\text { Kecakapan dosen untuk } \\
\text { menyelesaikan permasalahan } \\
\text { yang muncul sudah baik. }\end{array}$ & 0 & 0 & 24 & 140 & 35 & 199 & 3,98 \\
\hline 4 & $\begin{array}{l}\text { Kecakapan staf untuk } \\
\text { menyelesaikan permasalahan } \\
\text { yang muncul sudah baik }\end{array}$ & 0 & 0 & 48 & 124 & 15 & 187 & 3,74 \\
\hline 5 & $\begin{array}{l}\text { Saya jarang harus hilir mudik } \\
\text { ketika mencari informasi di } \\
\text { kampus ini. }\end{array}$ & 0 & 0 & 63 & 100 & 20 & 183 & 3,66 \\
\hline 6 & $\begin{array}{l}\text { Saluran untuk menyampaikan } \\
\text { keluhan-keluhan mahasiswa } \\
\text { tersedia dengan cepat }\end{array}$ & 0 & 0 & 78 & 88 & 10 & 176 & 3,52 \\
\hline & Rata-rata skor & 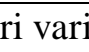 & & & 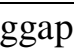 & & & 3,74 \\
\hline
\end{tabular}

Sumber: data primer yang diolah. 
Pada Tabel 9 data skor tertinggi sebesar 3,98 untuk pernyataan nomor 2 yaitu "Ketersediaan dosen untuk membantu mahasiswa sudah memadai" dan no. 3 "Kecakapan dosen untuk menyelesaikan permasalahan yang muncul sudah baik". Artinya mahasiswa merasakan bantuan yang diberikan dosen untuk keberhasilan studinya ataupun solusi atas persoalan akademik yang dihadapi.Untuk skor terendah sebesar 3,52 yaitu pernyataan nomor 6 "Saluran untuk mencapai keluhan-keluhan mahasiswa tersedia dengan cepat". Artinya mahasiswa belum merasa terbantu dengan sarana yang disediakan di kampus dalam mengatasi keluhan yang disampaikannya.

Tabel 10

Persepsi Mahasiswa Prodi Akuntansi Untuk Variabel Jaminan

\begin{tabular}{|c|c|c|c|c|c|c|c|c|}
\hline \multirow[t]{2}{*}{ No. } & \multirow[t]{2}{*}{ Keterangan } & \multicolumn{5}{|c|}{ Skor } & \multirow{2}{*}{$\begin{array}{l}\text { Total } \\
\text { skor }\end{array}$} & \multirow{2}{*}{$\begin{array}{c}\text { Rata- } \\
\text { rata }\end{array}$} \\
\hline & & STS & TS & CS & $\mathbf{S}$ & SS & & \\
\hline 1 & $\begin{array}{l}\text { Keramah-tamahan dan sopan } \\
\text { santun staf kampus sudah baik }\end{array}$ & 0 & 4 & 51 & 112 & 15 & 182 & 3,64 \\
\hline 2 & $\begin{array}{l}\text { Keramahan dan sopan santun } \\
\text { dosen baik }\end{array}$ & 0 & 0 & 24 & 152 & 20 & 196 & 3,92 \\
\hline 3 & $\begin{array}{l}\text { Produktifitas penelitian para } \\
\text { dosen sudah baik. }\end{array}$ & 0 & 0 & 24 & 152 & 20 & 196 & 3,92 \\
\hline 4 & $\begin{array}{l}\text { Dokumen akademis dari dosen } \\
\text { terjaga baik }\end{array}$ & 0 & 0 & 18 & 144 & 40 & 202 & 4,04 \\
\hline 5 & $\begin{array}{l}\text { Dosen sebagai agen perubahan } \\
\text { mahasiswa }\end{array}$ & 0 & 0 & 12 & 152 & 40 & 204 & 4,08 \\
\hline 6 & $\begin{array}{l}\text { Tingkat keterlibatan kampus } \\
\text { terhadap masyarakat sudah baik }\end{array}$ & 0 & 0 & 33 & 140 & 20 & 193 & 3,86 \\
\hline 7 & $\begin{array}{l}\text { Pengetahuan staf kampus pada } \\
\text { peraturan dan prosedur } \\
\text { akademik sudah baik }\end{array}$ & 0 & 0 & 48 & 124 & 15 & 187 & 3,74 \\
\hline 8 & $\begin{array}{l}\text { Jaminan keamanan kampus } \\
\text { sudah baik }\end{array}$ & 0 & 0 & 57 & 100 & 30 & 187 & 3,74 \\
\hline 9 & $\begin{array}{l}\text { Matakuliah diajarkan dengan } \\
\text { baik oleh dosen di kampus }\end{array}$ & 0 & 2 & 12 & 164 & 20 & 198 & 3,96 \\
\hline & Rata-rata sk & i v & & & & & & 3,88 \\
\hline
\end{tabular}

Sumber: data primer yang diolah.

Melalui Tabel 10 diketahui skor tertinggi sebesar 4,08 untuk pernyataan nomor 5 yaitu "Dosen sebagai agen perubahan bagi mahasiswa". Artinya mahasiswa dapat menghargai upaya dosen dalam mengubah mindset mahasiswa untuk memiliki arah masa depan yang lebih baik. Skor terendah sebesar 3,64 untuk pernyataan no.1 yaitu "Keramah-tamahan dan sopan santun staf kampus sudah baik". Artinya mahasiswa masih merasakan adanya kekurangan dari layanan yang dilakukan tenaga staf, khususnya mengenai keramah-tamahan dan sopan santun yang diberikan. 
Tabel 11

Persepsi Mahasiswa Prodi Akuntansi Untuk Variabel Empati

\begin{tabular}{|c|c|c|c|c|c|c|c|c|}
\hline \multirow[t]{2}{*}{ No. } & \multirow[t]{2}{*}{ Keterangan } & \multicolumn{5}{|c|}{ Skor } & \multirow{2}{*}{$\begin{array}{l}\text { Total } \\
\text { skor }\end{array}$} & \multirow{2}{*}{$\begin{array}{c}\text { Rata- } \\
\text { rata } \\
\text { skor }\end{array}$} \\
\hline & & STS & TS & $\mathbf{C S}$ & $\mathbf{S}$ & SS & & \\
\hline 1 & $\begin{array}{l}\text { Penatalaksanaan administrasi } \\
\text { memiliki ketertarikan terbaik di } \\
\text { hati mahasiswa }\end{array}$ & 0 & 0 & 36 & 144 & 10 & 190 & 3,8 \\
\hline 2 & $\begin{array}{l}\text { Akses ke fasilitas komputer } \\
\text { mengakomodir kenyamanan } \\
\text { mahasiswa sudah memadai }\end{array}$ & 0 & 0 & 66 & 104 & 10 & 180 & 3,6 \\
\hline 3 & Akses menuju ruang kelas mudah & 0 & 0 & 15 & 148 & 40 & 203 & 4,06 \\
\hline 4 & $\begin{array}{l}\text { Staf rela memberi perhatian } \\
\text { individu kepada mahasiswa sudah } \\
\text { memadai }\end{array}$ & 0 & 0 & 87 & 80 & 5 & 172 & 3,44 \\
\hline 5 & $\begin{array}{l}\text { Dosen mensupport kebutuhan } \\
\text { mahasiswa sudah memadai }\end{array}$ & 0 & 0 & 18 & 160 & 20 & 198 & 3,96 \\
\hline 6 & $\begin{array}{l}\text { Ruang komputer yang selalu } \\
\text { terbuka untuk mahasiswa sudah } \\
\text { memadai }\end{array}$ & 0 & 0 & 84 & 80 & 10 & 174 & 3,48 \\
\hline 7 & $\begin{array}{l}\text { Kampus bertindak adil dan tidak } \\
\text { memihak dalam memperlakukan } \\
\text { individu mahasiswa sudah } \\
\text { memadai }\end{array}$ & 0 & 0 & 24 & 136 & 40 & 200 & 4 \\
\hline
\end{tabular}

Sumber: Data primer yang diolah.

Dari Tabel 11 diketahui bahwa skor tertinggi dari rata-rata skor item empati adalah sebesar 4,06 untuk pernyataan nomor 3 yaitu "Akses menuju ruang kelas mudah".Artinya mahasiswa tidak mengalami kesulitan untuk menemukan ruang kuliah atau ruang kegiatan belajar lainnya sesuai dengan jadwal yang dibuat lembaga. Sedangkan skor terendah sebesar 3,44 untuk pernyataan nomor 4 "Staf rela memberi perhatian individu kepada mahasiswa sudah memadai. Artinya mahasiswa masih menginginkan perhatian secara individu yang lebih baik lagi dalam melayani kebutuhan mereka. 
Tabel 12

Persepsi Mahasiswa Prodi Akuntansi Untuk Variabel Bukti Fisik

\begin{tabular}{|c|c|c|c|c|c|c|c|c|}
\hline \multirow[t]{2}{*}{ No. } & \multirow[t]{2}{*}{ Keterangan } & \multicolumn{5}{|c|}{ Skor } & \multirow{2}{*}{$\begin{array}{l}\text { Total } \\
\text { skor }\end{array}$} & \multirow{2}{*}{$\begin{array}{l}\text { Rata } \\
\text {-rata } \\
\text { skor }\end{array}$} \\
\hline & & STS & TS & $\mathrm{CS}$ & $\mathbf{S}$ & SS & & \\
\hline 1 & $\begin{array}{l}\text { Penampilan (kebersihan dan } \\
\text { kerapian) para dosen dalam } \\
\text { berpakaian sudah baik }\end{array}$ & 0 & 0 & 3 & 136 & 75 & 214 & 4,28 \\
\hline 2 & $\begin{array}{l}\text { Penataan layout kelas sudah } \\
\text { baik }\end{array}$ & 0 & 0 & 36 & 124 & 35 & 195 & 3,9 \\
\hline 3 & $\begin{array}{l}\text { Pencahayaan dalam ruang } \\
\text { kelas memadai }\end{array}$ & 0 & 2 & 66 & 88 & 25 & 181 & 3,62 \\
\hline 4 & $\begin{array}{l}\text { Tampilan gedung kuliah } \\
\text { kampus baik }\end{array}$ & 0 & 8 & 69 & 80 & 15 & 172 & 3,44 \\
\hline 5 & $\begin{array}{l}\text { Tingkat kebersihan kampus } \\
\text { secara umum sudah baik }\end{array}$ & 0 & 10 & 63 & 76 & 25 & 174 & 3,48 \\
\hline 6 & $\begin{array}{l}\text { Peralatan pendukung belajar } \\
\text { (infokus, WI FI, dll.) sudah } \\
\text { baik }\end{array}$ & 1 & 24 & 60 & 60 & 10 & 155 & 3,10 \\
\hline 7 & $\begin{array}{l}\text { Atmosfir udara sudah } \\
\text { memadai }\end{array}$ & 0 & 2 & 69 & 92 & 15 & 178 & 3,56 \\
\hline 8 & $\begin{array}{l}\text { Penampilan (kebersihan dan } \\
\text { kerapian)para karyawan } \\
\text { sudah baik }\end{array}$ & 0 & 0 & 18 & 152 & 30 & 200 & 4 \\
\hline 9 & $\begin{array}{l}\text { Ketersediaan tempat parkir } \\
\text { sudah memadai }\end{array}$ & 1 & 4 & 27 & 112 & 50 & 194 & 3,88 \\
\hline 10 & $\begin{array}{l}\text { Kurikulum pendidikan yang } \\
\text { up to date sudah memadai }\end{array}$ & 0 & 4 & 24 & 140 & 25 & 193 & 3,86 \\
\hline 11 & $\begin{array}{l}\text { Banyaknya mata kuliah yang } \\
\text { ditawarkan sudah memadai }\end{array}$ & 0 & 2 & 15 & 148 & 35 & 200 & 4 \\
\hline 12 & $\begin{array}{l}\text { Kecukupan penyediaan } \\
\text { laboratorium komputer untuk } \\
\text { mahasiswa sudah memadai }\end{array}$ & 0 & 10 & 51 & 92 & 25 & 178 & 3,56 \\
\hline 13 & $\begin{array}{l}\text { Keterkinian (up to date) } \\
\text { komputer yang digunakan } \\
\text { sudah memadai }\end{array}$ & 1 & 12 & 27 & 124 & 15 & 179 & 3,58 \\
\hline 14 & $\begin{array}{l}\text { Keterkinian (up to date) } \\
\text { software komputer yang } \\
\text { digunakan sudah memadai }\end{array}$ & 0 & 8 & 36 & 124 & 15 & 183 & 3,66 \\
\hline 15 & $\begin{array}{l}\text { Akses internet sudah } \\
\text { memadai }\end{array}$ & 1 & 22 & 63 & 60 & 10 & 156 & 3,12 \\
\hline 16 & $\begin{array}{l}\text { Budaya kampus, keyakinan } \\
\text { dan nilai-nilai moral di } \\
\text { kampus ini sudah baik }\end{array}$ & 0 & 6 & 15 & 140 & 35 & 196 & 3,92 \\
\hline
\end{tabular}




\begin{tabular}{lllllllll}
\hline 17 & $\begin{array}{l}\text { Buku-buku perpustakaan } \\
\text { sudah memadai }\end{array}$ & 0 & 4 & 18 & 124 & 55 & 201 & 4,02 \\
\hline \multicolumn{2}{l}{ Rata-rata skor dari variabel Bukti Fisik } \\
\hline
\end{tabular}

Sumber: Data primer yang diolah.

Skor tertinggi untuk rata-rata skor item variabel bukti fisik adalah sebesar 4,28 untuk pernyataan nomor 1 yaitu "Penampilan (kebersihan dan kerapian) para dosen dalam berpakaian sudah baik. Artinya mahasiswa menyetujui cara berpakaian / penampilan dosen yang ada di lembaga ini. Sedangkan skor terendah sebesar 3,10 dengan pernyataan no.6 yaitu "Peralatan pendukung belajar (infokus, $\mathrm{WiFi}$, dan lain-lain) sudah baik". Artinya mahasiswa masih menemui kendala dalam proses belajar mengajar ketika membutuhkan peralatan pendukung belajar. Demikian pula untuk pernyataan nomor 15 "Akses internet sudah memadai" dengan skor 3,12 dapat diartikan bahwa mahasiswa belum sangat terbantu dengan fasilitas internet yang tersedia untuk memperoleh informasi yang dibutuhkannya.

Secara keseluruhan dapat dikatakan bahwa persepsi mahasiswa Prodi Akuntansi untuk kualitas pendidikan di Universitas Katolik Musi Charitas adalah mendekati baik untuk "variabel jaminan" dengan skor rata-rata tertinggi 3,88. Demikian pula dengan "variabel bukti fisik" persepsinya adalah mendekati baik dengan skor rata-rata terendah 3,70 .

\section{Uji Hipotesis Penelitian (Uji Beda)}

Sebelumnya telah dilakukan validitas dan reliabilitas atas 46 item butir pernyataan dan terbukti valid serta memiliki reliabilitas yang tinggi $(\alpha=0,9)$. Sebelum dilakukan uji beda, uji asumsi terlebih dahulu dilakukan untuk menentukan apakah akan digunakan uji perbedaan parametrik atau nonparametrik dalam analisis penelitian ini. Adapun uji asumsi yang dilakukan meliputi uji normalitas dan uji homogenitas.

Berdasarkan hasil uji normalitas yang telah dilakukan menggunakan uji Shapiro-Wilk ditemukan bahwa persepsi mahasiswa Prodi Akuntansi mengenai kualitas pendidikan di Unika Musi Charitas memiliki nilai p-value $=0,037$ $(\mathrm{p}<0,05)$ sedangkan persepsi mahasiswa Prodi Manajemen mengenai kualitas pendidikandi Unika Musi Charitas memiliki nilai p-value $=0,058$ ( $>>0,05)$. Hasil uji normalitas ini menunjukkan bahwa persepsi mahasiswa Prodi Akuntansi mengenai kualitas pendidikan di Unika Musi Charitas memiliki data yang tidak terdistribusi normal sedangkan persepsi mahasiswa Prodi Manajemen mengenai kualitas pendidikandi Unika Musi Charitas memiliki data yang terdistribusi normal. Hasil olah data dapat dilihat pada tabel 13 berikut ini.

Tabel 13

Uji Normalitas

\begin{tabular}{ccccccc}
\hline & \multicolumn{3}{c}{ Kolmogorov-Smirnov } & \multicolumn{3}{c}{ Shapiro-Wilk } \\
\hline $\begin{array}{c}\text { Program } \\
\text { Studi }\end{array}$ & Statistic & $\mathrm{df}$ & Sig & Statistic & $\mathrm{df}$ & Sig. \\
\hline Akuntansi & 0.116 & 50 & 0.087 & 0.951 & 50 & 0.037 \\
\hline Manajemen & 0.137 & 50 & 0.019 & 0.955 & 50 & 0.058 \\
\hline
\end{tabular}

Sumber: output spss 
Selanjutnya, berdasarkan hasil uji homogenitas yang telah dilakukan dengan menggunakan uji Levene ditemukan bahwa data memiliki p-value $=0,629$ ( $>0,05)$. Hasil uji homogenitas ini menunjukkan bahwa data diambil dari kedua kelompok yang memiliki variansi yang sama/homogen. Hasil olah data dapat dilihat pada tabel 14 di bawah ini.

Tabel 14

Uji Homogenitas

Kualitas Layanan

\begin{tabular}{cccc}
\hline Levene Statistic & df1 & df2 & Sig. \\
\hline .235 & 1 & 98 & .629 \\
\hline
\end{tabular}

Sumber: output spss

Dikarenakan salah satu hasil uji normalitas menunjukkan bahwa persepsi mahasiswa Prodi Akuntansi mengenai kualitas pendidikan di Unika Musi Charitas memiliki data yang tidak terdistribusi normal, maka uji perbedaan yang dilakukan menggunakan uji perbedaan non-parametrik Mann Whitney.

Berdasarkan hasil uji perbedaan dengan menggunakan Mann Whitney mengindikasikan bahwa persepsi mahasiswa Akuntansi mengenai kualitas layanan (Median=2143) secara umum berbeda dengan persepsi mahasiswa Manajemen mengenai kualitas layanan (Median=2907) dengan signifikansi 0,008 $<0,05$. Jika dilihat berdasarkan masing-masing variabel tampak bahwa:

1. Terdapat perbedaan persepsi mengenai keandalan/reliability antara mahasiswa Program Studi Akuntansi $(M d n=2053)$ dengan persepsi mahasiswa Program Studi Manajemen (Mdn=2997), dan dilihat dari nilai signifikannya adalah $0,001<0,05$. Kondisi ini dapat diartikan bahwa mahasiswa Akuntansi dengan mahasiswa Manajemen memberikan penilaian berbeda mengenai penilaian registrasi yang tepat waktu dan tanpa kesalahan, kampus yang dapat menyimpan data akademik dengan teliti, keandalan dosen dalam memenuhi kewajibannya, kesungguhan staf dalam melayani dengan tulus dalam menyelesaikan masalah mahasiswa, kampus yang memberikan pelayanan sesuai dengan yang dijanjikan, kemampuan dosen dalam mengajar, serta perhatian yang tulus dari dosen dalam mencari solusi persoalan.

2. Terdapat perbedaan persepsi mengenai daya tanggap/responsiveness antara mahasiswa Program Studi Akuntansi $(M d n=2231,50)$ dengan persepsi mahasiswa Program Studi Manajemen $(\mathrm{Mdn}=2818,50)$, dan signifikansi adalah $0,004<0,05$. Artinya mahasiswa Akuntansi memiliki persepsi yang berbeda dengan mahasiswa Manajemen mengenai segala sesuatu yang mereka rasakan sebagai daya tanggap dari lembaga pendidikan mengenai ketersediaan karyawan untuk membantu mahasiswa, ketersediaan dosen untuk membantu mahasiswa, kecakapan dosen untuk menyelesaikan permasalahan yang muncul, tidak membuat mahasiswa hilir mudik ketika mencari informasi di kampus, serta saluran untuk menyampaikan keluhan-keluhan mahasiswa tersedia dengan cepat. 
3. Terdapat perbedaan persepsi mengenai jaminan/assurance antara mahasiswa Program Studi Akuntansi ( $M d n=2032$ ) dengan persepsi mahasiswa Program Studi Manajemen $(M d n=3018)$, dan signifikansi adalah 0,001 $<0,05$. Artinya mahasiswa Akuntansi memberikan penilaian yang berbeda dengan mahasiswa Manajemen untuk variabel jaminan dari kualitas jasa pendidikan meliputi keramah tamahan dan sopan santun dari staf kampus serta dosen, produktifitas penelitian dosen, dokumen akademis dosen yang terjaga baik, dosen sebagai agen perubahan bagi mahasiswa, tingkat keterlibatan kampus terhadap masyarakat, pengetahuan staf kampus pada peraturan dan prosedur akademik, jaminan keamanan kampus, kemampuan komunikasi dosen untuk mengajarkan mata kuliah dengan baik.

4. Tidak terdapat perbedaan persepsi mengenai empati/emphaty antara mahasiswa Program Studi Akuntansi $(\mathrm{Mdn}=2256)$ dengan persepsi mahasiswa Program Studi Manajemen $(M d n=2794)$, karena signifikansinya adalah 0,061 $>$ 0,05. Artinya baik mahasiswa Program Studi Akuntansi maupun Manajemen memiliki persepsi yang sama mengenai berbagai hal yang berkaitan dengan empati yaitu: penatalaksanaan administrasi, akses ke fasilitas komputer, kemudahan akses menuju ruang kelas, staf rela memberi perhatian individu kepada mahasiswa. Selain itu juga, dosen mensupport kebutuhan mahasiswa dengan baik, ruang komputer yang selalu terbuka untuk mahasiswa sudah memadai, dan kampus bertindak adil dan tidak memihak dalam memperlakukan individu mahasiswa sudah memadai.

5. Tidak terdapat perbedaan persepsi mengenai bukti fisik/tangibility antara mahasiswa Program Studi Akuntansi $(\mathrm{Mdn}=2368)$ dengan persepsi mahasiswa Program Studi Manajemen ( $M d n=2682)$, dan signifikansi adalah 0,278 > 0,05. Artinya mahasiswa Program Studi Akuntansi dan Manajemen memiliki pendapat yang sama untuk variabel bukti fisik meliputi penampilan para dosen dalam berpakaian, penataan layout kelas, pencahayaan kelas, tampilan gedung kampus, tingkat kebersihan kampus, peralatan pendukung belajar, atmosfir udara, penampilan para karyawan, ketersediaan tempat parkir, kurikulum pendidikan yang up to date, matakuliah yang ditawarkan, kecukupan penyediaan laboratorium komputer, keterkinian komputer yang digunakan, keterkinian software komputer yang digunakan, akses internet yang memadai, budaya kampus, keyakinan dan nilai-nilai moral di kampus, dan buku-buku perpustakaan yang memadai.

\section{KESIMPULAN DAN IMPLIKASI \\ Kesimpulan}

Melalui pengujian analisis deskriptif terbukti bahwa Secara keseluruhan persepsi mahasiswa Prodi Manajemen untuk kualitas pendidikan di Universitas Katolik Musi Charitas adalah baik untuk "variabel jaminan" dengan skor rata-rata tertinggi 4,13. Akan tetapi untuk "variabel bukti fisik" persepsinya adalah mendekati baik dengan skor rata-rata terendah 3,79. Sedangkan persepsi mahasiswa Prodi Akuntansi untuk kualitas pendidikan di Universitas Katolik Musi Charitas adalah mendekati baik untuk "variabel jaminan" dengan skor rata- 
rata tertinggi 3,88. Demikian pula dengan "variabel bukti fisik" dengan skor ratarata terendah 3,70. Dari hasil penelitian ini diketahui bahwa persepsi mahasiswa Prodi Manajemen atau Akuntansi sama-sama memberikan penilaian dengan skor tertinggi untuk variabel jaminan, dan skor terendah pada variabel bukti fisik.Untuk variabel bukti fisik persepsi mahasiswa Prodi Manajemen dan Akuntansi sama-sama memberikan penilaian mendekati setuju. Akan tetapi, untuk variabel jaminan terdapat penilaian yang berbeda, dimana mahasiswa Prodi Manajemen lebih dapat menerima untuk variabel jaminan sedangkan mahasiswa Prodi Akuntansi hanya memberikan penilaian cukup setuju (mendekati setuju) yang berarti belum merasakan layanan yang maksimal berkaitan dengan faktor jaminan yang meliputi keramah-tamahan dan sopan santun staf kampus, keramahtamahan dan sopan santun dosen kampus, produktifitas penelitian para dosen, dokumen akademis dari dosen yang terjaga dengan baik, dosen sebagai agen perubahan bagi mahasiswa, tingkat keterlibatan kampus terhadap masyarakat, pengetahuan staf kampus pada peraturan dan prosedur akademik, jaminan keamanan kampus, dan kemampuan dalam berkomunikasi pada mata kuliah yang diajarkan dosen. Artinya institusi harus lebih lagi memperhatikan unsur sumber daya manusia yang dipekerjakan. Karena melalui tenaga kerja yang kompeten akan lebih mampu meyakinkan pengguna jasa untuk mempercayai jaminan yang diberikan oleh lembaga pendidikan yang dipilihnya. Sesuai dengan hasil penelitian dari Haryadi, dkk. (2005) yang menyatakan bahwa pentingnya mengutamakan Sumber Daya Manusia bukan hanya fasilitas dan sarana fisik. Walaupun perlu diakui juga bahwa fasilitas dan sarana fisik juga perlu diperhatikan dalam memberikan kepuasan kepada para mahasiswa. Dari hasil penelitian diketahui bahwa baik mahasiswa Program Studi Manajemen dan Akuntansi hanya menunjukkan persepsi yang cukup setuju saja dari bukti fisik yang tersedia di Universitas Katolik Musi Charitas.

Berdasarkan hasil uji perbedaan dengan menggunakan Mann Whitney terbukti bahwa terdapat perbedaan persepsi mahasiswa program studi Akuntansi dan Manajemen terhadap kualitas layanan jasa pendidikan yang meliputi variabel keandalan, daya tanggap, dan jaminan. Sedangkan untuk variabel empati dan bukti fisik tidak terdapat perbedaan persepsi.

Untuk data mahasiswa seperti yang ditunjukkan pada table 2 yaitu adanya perbedaan jumlah mahasiswa antara mereka yang registrasi dengan yang lulus dikaitkan dengan kualitas layanan jasa di Universitas Katolik Musi Charitas, maka dapat diartikan bahwa mahasiswa yang tidak menyelesaikan kuliahnya masih menemukan adanya ketidaksetujuan mereka atas layanan yang diberikan. Atau dapat pula diartikan adanya kendala yang dihadapi sebagian besar mahasiswa dalam menyelesaikan studinya seperti desakan ekonomi keluarga yang mendorong mereka untuk memilih bekerja daripada kuliah, ketidaksesuaian program studi yang dipilih, atau kurangnya motivasi dari diri sendiri dan orangorang terdekat mengenai pentingnya kesarjanaan yang perlu diperjuangkan.

\section{Implikasi}

Implikasi hasil penelitian ini bagi Universitas Musi Charitas adalah:

1. Mengupayakan perbaikan yang diperlukan untuk dapat memberikan dukungan yang sangat berarti baik bagi sumber daya manusia yang dipekerjakan, 
maupun bagi para mahasiswa sebagai pengguna jasa. Perbaikan yang dimaksudkan terutama melengkapi peralatan pendukung proses belajar mengajar seperti infocus, Wi Fi, dan juga akses internet yang memudahkan dosen dan khususnya para mahasiswa untuk mendapatkan informasi yang diperlukan.

2. Lebih memberikan perhatian khususnya kepada karyawan agar mereka mendapatkan kepuasan dalam bekerja di institusi pendidikan ini. Cara yang dapat dilakukan misalnya dengan memberikan seminar, pelatihan, kesempatan studi atau bimbingan khusus kepada individu yang membutuhkan.

\section{Saran}

Beberapa saran yang dapat disampaikan adalah sebagai berikut:

1. Adanya keterbatasan dari pelaksanaan penelitian ini seperti sampel yang digunakan masih dirasakan kurang banyak. Akan lebih baik jika menggunakan jumlah sampel yang lebih besar lagi, sehingga hasil penelitian dapat lebih mewakili jawaban dari permasalahan penelitian.

2. Dapat diteliti juga dengan menggunakan teknik analisis regresi yaitu untuk mengetahui pengaruh kualitas jasa pendidikan terhadap kepuasan mahasiswa Unika Musi Charitas.

\section{DAFTAR PUSTAKA}

Ghozali, Imam. 2006. Aplikasi Analisis Multivariate dengan Program SPSS. Cetakan IV. Universitas Diponegoro. Semarang.

Haryadi, Bambang, Soekarno, dan Llewelyn, Richard. 2005. Persepsi Kualitas Pendidikan, Fasilitas, dan Staf Pengajar di Fakultas Ekonomi, Universitas Kristen Petra, Surabaya

Ilyas, Imran. 2013. Pengaruh Persepsi Kualitas Pelayanan dan Persepsi Biaya Pendidikan Terhadap Kepuasan dan Loyalitas Mahasiswa/i. STIE Pembangunan Tanjung Pinang. Koleksi Perpustakaan Universitas Terbuka, Program Pasca Sarjana UT, Jakarta

Kotler, Philip dan Armstong, Gary. 2008. Prinsip-Prinsip Pemasaran. Jilid 1. Penerbit Erlangga, Jakarta.

Lovelock, C., dan L. Wright. 1990. Principles of Service Marketing and Management. New Jersey. Pearson Education, Inc.

Munandir. 2002. "Pengaruh Bimbingan Belajar Terhadap Sikap, Minat, Motivasi, dan Prestasi Belajar Siswa SMU di Kota Makassar". Jurnal Insani. 6(2):21-29.

Munawaroh, Munjiati. 2005. Analisis Pengaruh Kualitas Jasa Terhadap Kepuasan Pada Industri Pendidikan di Yogyakarta. Edisi Khusus JSB ON Marketing

Owlia, M.S., dan E.M. Aspinwall. 1997. “TQM in higher education”. Journal of Quality and Reliability Management. 14(5): 47-59.

Parasuraman, Zeithaml, A.V. dan Berry L.L. (1985), 'A Conceptual Model of Service Quality’, Journal of Retailing, Vol.67:420-450

Sugiyono (2004). Metode Penelitian Bisnis. Alfabeta, CV. Bandung.

Robbins, Stephen P. 1998. Organizational Behavior.8th edition. New Jersey. Prentice Hall. 
Schiffman, L.G., dan L.L. Kanuk. 2002. Consumer Behavior. 7th edition. New Jersey. Prentice Hall.

Sekaran, Uma. 2016. Research Methods For Business (Metodologi Penelitian untuk Bisnis). Buku 2. Edisi 4. Penerbit Salemba Empat. Jakarta.

Sulastiyono. 1999. Pengantar Ilmu Perpustakaan. PT. Gramedia Pustaka Utama. Jakarta. 